University of Louisville

ThinkIR: The University of Louisville's Institutional Repository

$5-1989$

\title{
John F. Kennedy, Ghana and the Volta River project : a study in American foreign policy towards neutralist Africa.
}

Kurt X. Metzmeier 1959-

University of Louisville

Follow this and additional works at: https://ir.library.louisville.edu/etd

\section{Recommended Citation}

Metzmeier, Kurt X. 1959-, "John F. Kennedy, Ghana and the Volta River project : a study in American foreign policy towards neutralist Africa." (1989). Electronic Theses and Dissertations. Paper 967. https://doi.org/10.18297/etd/967

This Master's Thesis is brought to you for free and open access by ThinkIR: The University of Louisville's Institutional Repository. It has been accepted for inclusion in Electronic Theses and Dissertations by an authorized administrator of ThinkIR: The University of Louisville's Institutional Repository. This title appears here courtesy of the author, who has retained all other copyrights. For more information, please contact thinkir@louisville.edu. 
JOHN F. KENNEDY, GHANA AND THE

VOLTA RIVER PROJECT

A Study in American Foreign Policy towards Neutralist Africa

By

Kurt X. Metzmeier

B.A., University of Louisville, 1982

\begin{abstract}
A Thesis
Submitted to the Faculty of the

Graduate School of the University of Louisville in Partial Fulfillment of the Requirements

for the Degree of
\end{abstract}

Master of Arts

Department of History

University of Louisville

Louisville, Kentucky

May 1989 
JOHN F. KENNEDY, GHANA AND THE

VOLTA RIVER PROJECT

A Study in American Foreign Policy Towards Neutralist Africa

By

Kurt $\mathrm{X}$. Metzmeier

B.A., University of Louisville, 1982

A Thesis Approved on

April 26, 1989

(DATE)

By the following Reading Committee:

Thesis Director 


\section{ABSTRACT}

The emergence of an independent neutralist Africa changed the dynamics of the cold war. The militarystrategic orientation of the United States and Soviet Union had little relevance to underdeveloped Africa. Following the death of Joseph Stalin, the USSR began to discard the ideological impediments which had hampered their relations with neutralist Africa, byt the United States under the Eisenhower Administration continued to oppose the neutralist doctrine.

John F. Kennedy came to office determined to bring a new dynamism to United States foreign policy towards Africa. He declared a new tolerance of neutralism. The decision whether to give foreign aid to Kwame Nkrumah's Volta River project became a test case for the Kennedy administration's new policy toward the neutralist states of Africa.

The decision to support the project was a concrete manifestation of that policy. For Kennedy's purposes, it mattered little whether the project failed or succeeded. What was important was that the United States was visibly competing for the trust of neutralist Africa. 
CHAPTER

I. THE COLD WAR, AFRICAN INDEPENDENCE AND THE RISE OF THIRD WORLD NEUTRALISM . . . . . . • . 5

II. THE SOVIET UNION AND AFRICAN NEUTRALISM, $1945-1960$. . . . . . . . . . . . . 17

III. THE UNITED STATES AND AFRICAN NEUTRALISM,

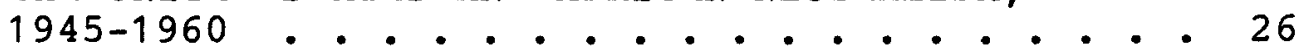

IV. THE NEW FRONTIER AND NEUTRALIST AFRICA . . . . 38

V. KWAME NKRUMAH AND GHANA'S INDEPENDENCE STRUGGLE . . . . . . . . . . . . . 55

VI. ORIGINS OF GHANAIAN FOREIGN POLICY . . . . . 62

VII. GHANA AND THE EISENHOWER ADMINISTRATION,

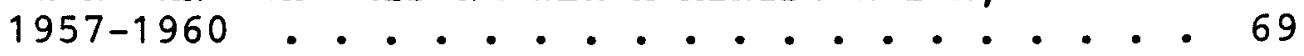

VIII. KENNEDY, THE VOLTA DAM PROJECT AND THE UNITED STATES POLICY TOWARD NEUTRALISM IN PRACTICE ............... . 82 CONCLUSION . . . . . . . . . . . . . . . 94 BIBLIOGRAPHY . . . . . . . . . . . . 99

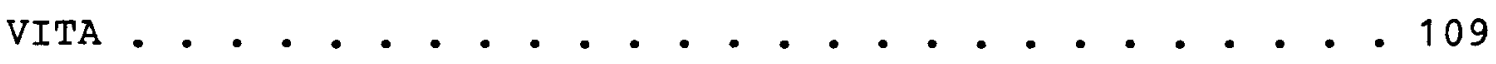




\section{INTRODUCTION}

In late 1961, the governments of U.S. President John F. Kennedy and Kwame Nkrumah of Ghana came to an agreement to build a hydroelectric dam over the Volta River in Ghana. For Nkrumah, it was the culmination of a fiveyear effort that had many times forced him to submerge his African nationalist and anti-imperialist impulses. For Kennedy, the Volta Dam project was a concrete example of America's commitment to the aspirations and economic development of Africa, and his own tolerance of African neutralism. The road to this point in history had not been an easy one for either man. For decades the United States had ignored Africa.

But the dawning of the 1960s saw the emergence of forces pregnant with implications for American foreign policy. In the first half of the twentieth century, American policy was irresistibly drawn toward the political and diplomatic battlefields of Europe. The world wars had oriented two generations of American policymakers to see international relations through European eyes. From stettin to Trieste, the center of foreign policy discussion was Europe. Heading into the 1960s, the foreign policy establishment still consisted of men who had led the struggle to save Europe from Nazism and to rebuild it as a bulwark against communism. They had worked alongside the 
able of men of Britain and France, absorbing their world view and prejudices.

World War II had unleashed forces that these men were unprepared to recognize or understand. For centuries, through a mixture of brutal force and paternalism, Europe had suppressed the national aspirations of two-thirds of the world's peoples. But while the imperial powers of Europe had won the war against Hitler, they no longer had either the strength or, in Britain's case, the inclination to hold together their colonial empires. Japan's triumphs in the East early in the war had shattered the myth of European racial superiority. From French Algeria to British Iraq to Dutch Indonesia the demands for freedom were heard. In 1947, India gained its independence. A new era in world affairs had begun.

The decolonization of Asia and Africa created a new force in international affairs. Nations long held in thrall were unwilling to subordinate their hard-won independence to one of the two cold war powers. In a series of conferences during the 1950s, the emerging nations of Asia and Africa defined an idea of neutralism. At its core, neutralism was the rejection of the cold war bloc system represented by NATO and the Warsaw pact, and the variations that the United States was promoting (i.e., CENTO, SEATO, etc.). It did not mean neutrality in the great international concerns of peace, economic development, and human rights. It did mean 
that the new nations would not be easily integrated into the strategic plans of the United States and the Soviet Union.

In 1957 Kwame Nkrumah stepped onto the world stage as the Prime Minister of Ghana, the first black African nation to attain independence. Nkrumah, a graduate of Lincoln University and the University of Pennsylvania, guickly established himself to the world as Africa's foremost champion. From 1957 to 1961, more than twenty-five African states emerged from colonialism to take their places in the United Nations. The year of 1960 was declared the "Year of Africa." It was to be the beginning of a decade that would set the future course of American policy toward Africa. The question of U.S. support for Ghana's Volta Dam project was to be among the most important African policy decisions the winner of the 1960 presidential election would face.

The purpose of this thesis is to examine the background of the U.S. decision to fund the Volta Dam project. It will attempt to place that decision in the light of historic changes in international politics brought about by the decolonization of Africa and the rise of the neutralist movement, and to assess whether it represented a break with the cold war orientation of American foreign policy or merely a complex refinement. Finally, an effort will be made to suggest the impact that the Kennedy 
administration's policy toward Ghana may have had over the last 25 years of American policy on the African continent. 
CHAPTER I

THE COLD WAR, AFRICAN INDEPENDENCE AND

THE RISE OF THIRD WORLD NEUTRALISM

International politics following the Second World War have been marked by two events of particular importance: the cold war between American and the Soviet Union, which divided the world into two mutually exclusive camps; and the decolonization and enfranchisement in the international community of one-third of the world's population. The combination of these factors created a "third force" in world politics--those nations among the underdeveloped world who chose to disassociate themselves from the cold war and pursue independent foreign policies, which were based on their own interests, not those of the superpowers.

The first major response of the U.S. to the challenge of the Soviet Union was the development of the containment doctrine. Formulated in the Truman administration by George F. Kennan, containment was based on Kennan's interpretation of the Marxist-Leninist belief that the victory of socialism over capitalism was inevitable. He believed this doctrine caused Soviet foreign policy to be cautious, persistent and far-sighted. "In these circumstances," Kennan wrote, "it is clear that the main element of United States policy toward the Soviet Union must be that of a firm and vigilant containment of Russian 
tendencies."1 The practical result of the containment theory was the creation of a system of formal alliances, beginning with the Treaty of Rome in 1949, which established the North Atlantic Treaty Organization (NATO) for the mutual defense of the United States and Western Europe. This policy of collective defense was continued by Secretary of State John Foster Dulles, who created similar pacts in Latin America (the Rio Pact), the Middle East (the Baghdad Pact) and Asia (SEATO). The USSR also formed its own military alliance in the Warsaw Pact of 1955. By the time the nations of the third world emerged from dependence, the world was divided into two rigid camps.

The World War had an enormous impact on the old colonial empires. Six long years of total war had drained the resources of Britain and France, and the United States was unsympathetic to their attempts to retain their empires. While the war had weakened the imperial powers, it had invigorated the African nationalists in the colonies, whose returning veterans were demanding freedom as a reward for their loyalty. In Britain, France and other colonial nations, policymakers were more concerned with rebuilding their own economies, than with retaining a costly colonial system. European governments began to plan for the eventual orderly transition to independence. In 1947, Governor Lord Louis Mountbatten presided over the peaceful end of English rule in India. The following year brought the independence 
of the remainder of British Asia. In 1949, the Dutch East Indies were dissolved and free Indonesia emerged, led the by veteran nationalist, Sukarno. Following the French defeat at Dien Bien Phu in 1954, France relinquished control in Indochina.

The hopes of African nationalists were intensified by these events, and they stepped up attempts to organize for the independence struggle while at the same time encouraging the progress of European plans for peaceful decolonization. Among the more prominent of the African nationalists was Kwame Nkrumah, who pioneered African use of non-violent protest in the early fifties. Nkrumah demonstrated his popularity in 1954 when he was elected leader of the Gold Coast (Ghana) in British supervised elections.

In 1957, Ghana peacefully became the first new independent state in black Africa since the establishment of Liberia in 1830. In 1958 French President Charles de Gaulle offered the territories of French Africa a choice of independence or self-determination in association with France. Only one nation voted for independence, Guinea, whose popular leader Sekou Toure had told de Gaulle that he would rather be "destitute in freedom, than rich in slavery." De Gaulle reacted ruthlessly to the vote of "non," withdrawing all French assistance, technical aid, records and material. He meant to punish Guinea, and cow 
the African nations still associated with France. ${ }^{2}$

The events of 1957 and 1958 were dwarfed by those of 1960, which saw the independence of seventeen new African states, and dramatically changed the composition of the United Nations and world politics in general. The stage was set for the emergence of a third force in international affairs--neutralism led by the Afro-Asian states.

Attempts to organize the emerging Afro-Asian states dates back to 1957, when newly independent India, led by Prime Minister Jawarharlal Nehru sponsored the Asian Relations Conference in New Dehli. It was attended by twenty-eight Afro-Asian nations. The follow-up congress in 1949, was attended by fifteen nations. In his speeches before these conferences, Nehru stressed that the "Asian sentiment" for peace and independence should not be ignored by the United States and the Soviet Union. In later AfroAsian conferences held in the late fifties Nehru reacted strongly to the recently created system of alliances (SEATO in particular) which he felt threatened to entangle AfroAsia in the cold war. He began to press for a positive policy of neutralism in the cold war, combined with an active policy of encouraging peaceful settlement of international disputes. The active portion of this policy of non-alignment was incorporated into the April 1954 SinoIndian Trade Agreement, and is known as the "five principles." These include: respect for territorial 
integrity and sovereignty; non-aggression; noninterference in the internal affairs of others; equality and mutual benefit, and peaceful co-existence. ${ }^{3}$

These early conferences were largely ignored outside of Asia because they were sparsely attended and dominated by Nehru (which caused observers to dismiss them as a soapbox for his neutralist views). But the 1955 Bandung conference was more representative of the Afro-Asian world (twenty-nine states were represented) and was attended by personalities strong enough to challenge Nehru. Because the conference was attended by both committed and non-aligned Afro-Asian nations, it was the forum for a spirited debate on the position of the third world in the cold war. The prowestern states represented were Jordan, Iran, Iraq, Pakistan, Libya, Lebanon, Turkey, Ethiopia, the Philippines, Ceylon, Thailand, Burma, Afghanistan, Sudan, South Vietnam, Japan and Liberia. The self-designated neutralist nations included India, Cambodia, Laos, North Vietnam, China, Nepal, North Korea, Egypt, Ghana, and Syria. Tensions between these two groups were subdued until the debate over the usefulness of military pacts, which occurred in the closing days of the conference.

The debate began with a comprehensive defense of alignment by General zorlu of Turkey, drawing on his nation's experience with Russia. His argument that collective security pacts were the only means of defense for 
the small nations was passionately criticized by Nehru in a speech which had a great impact on the conference.

I belong to neither bloc and I propose to belong to neither whatever happens in the world. . . I am afraid of nobody. I suffer from no fear complex. My country suffers from no fear complex. We rely on nobody except on the friendship of others, we rely on ourselves and none other. . . Even a single country can make a difference when the scales are evenly balanced. . . . If I join any of these big groups I lose my identity, I have no views left. . . . If all the world were to be divided up between these two blocs what would be the result? The inevitable result would be war. . . . It is an intolerably thought to me that the great countries of Asia and Africa should come out of bondage into freedom only to degrade and humiliate themselves in this way. - Every pact has brought insecurity and not security to the countries which have entered into them ... the so-called Five Principles . . . is not a magic formula. - . It is something which meets the needs of the day. - . Unless one thinks that there is no alternative to this except war, and to be prepared for war, this... has to be accepted.

The aligned nations made an attempt to counter Nehru's assertions but were unable to match the influence of his arguments. An Iraqi delegate asked mockingly, "Are you ready to bring us together the weak and small nations--and form another bloc? - . But by not doing that you leave us alone in small entities, cut to pieces and our existence threatened every moment." Carlos Romulo of the Philippines defended his SEATO membership, "It was made out that it was humiliating for us to join a regional group. As a matter of fact, we would not like to do so but we have to defend ourselves." 5

Despite the large representation the Bandung conference was an Asian affair, influenced by the pacifistic 
Indian form of neutralism and focused on issues of concern to Asians, such as collective defense pacts, UN representation for China, and peaceful settlement of disputes through the UN. Africa and its prime concern, colonialism, were shunted aside. Only three black African states were represented, and it took great efforts by one Liberian to obtain a seat on the colonial drafting committee. 6

The Bandung conference is often cited as the $\iota$ beginning of the non-aligned movement, but it actually signaled the end to the Asian-phase of neutralism dominated by Nehru's strong commitment to the peaceful settlement of disputes at any cost. The new phase would be dominated by Arabs and Africans, who envisioned a more militant mission for neutralism. By 1955 it seemed clear to Arabs and Africans that Palestine and dependent Africa would not be liberated by Nehruist conciliation. The leader of this new phase was Egypt's president, Abdel Gamal Nasser, who in late 1957 hosted the First Afro-Asian Peoples Solidarity conference. Nasser, who had recently rebuffed the attempt of France, Britain and Israel to seize the Suez Canal, focused the conference squarely on the question of colonialism and imperialism. This was revealed in the opening speech by Anwar Sadat, a blistering attack on colonialism. The conference formed liberation committees for each of the colonial territories, and its closing 
communique condemned "imperialism in all its forms and manifestations."7 Yet despite the large number of Africans involved, and the anti-colonial resolutions, Africans were not influential at the conference. Until more African nations were independent they would have no real voice in neutralist politics.

The First and Second All African Peoples Congresses held at Accra in 1958 were the first conferences attended by solely African sovereign states which dealt with uniquely African problems. Of the eight nations represented, four were pro-Western (Ethiopia, Libya, Liberia and Sudan) and four were neutralist (Ghana, Egypt, Morocco and Tunisia), so the Accra conferences revealed the areas of common agreement across ideological boundaries. Among the points of agreement were: a call for majority rule; the importance of African unity; and the desire to keep the cold war out of Africa. 8

Unlike Asia where the definite threat of Soviet or Chinese expansionism forced many newly independent states to align directly with the West, Africa did not face such a threat and both radicals and moderates were in agreement over the need to avoid such pressure.

There were two principles on which African nonalignment was based. The first was the theory of continental sovereignty, the belief that the Africans should be able to manage their affairs without the harassment of 
the outside world.

Closely related concepts were "pan-Africanism," which sought to unify Africa into a single nation-state, and "the African personality," the idea that there is a common African civilization which unites all Africans and contains lessons for the western world. An extreme example of the belief in continental sovereignty was revealed in Nkrumah's speech welcoming the delegates to the Accra conferences.

Three alternatives are open to African states; first to unite and to save our continent; secondly to continue in disunity and to disintegrate; or thirdly to sell out and capitulate before the forces of imperialism and neocolonialism. As each year passes $g$ our failure to unite strengthens our enemies. . .

The second principle behind African non-alignment was the idea of "positive" or "active" neutralism. This principle held that Africa's desire to remain outside of the cold war did not preclude an active foreign policy in pursuit of such goals as world peace, self-determination, and international justice. The policy was as important to pro-western regimes as it was to the radicals who designed it. Thus in the 1959 issue of Foreign Affairs, conservative Nigerian President Sir Abubaker Tafawa Balewa states:

Our foreign policy has never been one of neutrality, but rather non-alignment. We have never been neutral in African affairs, nor can we be neutral in matters pertaining to world peace.

And within the same issue the radical President of Guinea Sekou Toure wrote: 
African neutralism, then, is not shameful indifference. - . It is something active, a participating force, an active agent in the struggle for the achievement if a
world society--emancipated, fraternal and united.

The unity of the Accra conference was unable to survive the impact of the proliferation of states in 1960, especially the more conservative ex-French community members, and the Congo crisis which by its nature split Africa. In late 1960 the francophone states, with the notable exceptions of Guinea, Mali and Togo, met at Brazzaville and Abidjan to discuss plans for economic union. Among the resolutions passed were ones supporting the UN mission in the Congo and de Gaulle's idea for a referendum in Algeria. In reaction, the five radical states, Guinea, Ghana, Mali, Egypt and Morocco, met in January 1961 at Casablanca, and passed a set of resolutions almost completely opposite from the Brazzaville and Abidjan agreements. They condemned the UN mission, and the Algerian referendum. ${ }^{12}$ The matter was further confused when the Monrovia conference was held in January 1962. Several African nations attended; they did not include the Casablanca group.

It would seem that the split in Africa was ideological and must have changed views toward neutralism. But the resolutions passed by the three conferences reveal no difference over the issue of neutralism. There is also little evidence that the rift caused a greater alignment with the superpowers. With the end of the Congo conflict in 
1961, and Algerian independence in 1962, tensions cooled to the point that by 1963 all nations were able to agree to a charter for an Organization of African States, based on the principles of continental sovereignty and positive neutralism. 
Endnotes

1 [George F. Kennan], "The Sources of Soviet Conduct," Foreign-Affairs 25 (July 1947): 566-82.

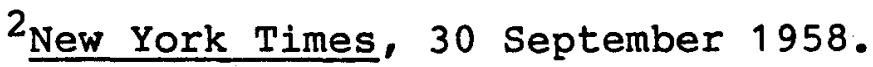

${ }^{3}$ Stanley Wolpert, A New History of India (New York: Oxford University Press, 1979), 365.

${ }^{4}$ G. H. Jansen, Afro-Asia and Non-alignment (London: Faber and Faber, 1966), 209.

${ }^{5}$ Ibid., 210.

6 Ibid., 233, 200.

${ }^{7}$ Ibid., 211.

${ }^{8}$ Declaration and Resolutions of the First Conference of Independent African States, Accra, Ghana, April 15-20, 1958. African Studies Pamphlet Collections, Indiana University Library.

${ }^{9}$ Kwame Nkrumah, The Revolutionary Path (New York: International Publishers, 1973), 125.

${ }^{10}$ Sir Abubakar Tafawa Balewa, "Nigeria Looks Ahead," Foreign Affairs 41 (October 1962): 131-40.

${ }^{11}$ sekou Toure, "Africa's Future and the World," Foreign Affairs 41 (October 1962): 141-51.

12 Victor Bakpetu Thompson, Africa and Unity: The Evolution of Pan-Africanism (New York: Humanities Press, 1970). 
CHAPTER II

THE SOVIET UNION AND AFRICAN NEUTRALISM,

$1945-1960$

The Bandung conference had a great impact on Soviet theorists and policy-makers. It showed them that the anticolonial movement was poised on the edge of success, led by the very national-bourgeois leaders they had denounced for years as "servants of imperialism," who had "already proved their incapability of pursuing the course of national liberation." "1

The policy towards the developing world, which the Bandung conference provoked the Soviets to reevaluate, had roots back to the early years of the revolution. By 1920, Lenin began to see that revolution in Europe was not as near and inevitable as he had once thought, and began to look to the East, which he believed had "been definitely drawn into the maelstrom of the world revolutionary movement." In his theses on colonialism of the Sixth Party Congress, Lenin asserted that the national liberation movements in the colonies "only salvation is the victory of Soviet power over world imperialism." Within the third world, communists must only support the "bourgeois-democratic national movements' on the condition that they allow the creation of proletarian parties "educated to understand their special task--to fight the bourgeois-democratic movements within their own 
country."2 Thus the Soviets would only support nationalists who would allow rival parties committed to their eventual destruction. This point was reinforced by the Sixth World Congress of the Comintern's 1928 Theses, which urged local communists to exploit the independence struggle to achieve "the basic strategic aim of the Communist Movement in the bourgeois-democratic revolution--the hegemony of the proletariat."3 They were also instructed to fight such "class traitors" as M. K. Gandhi and Sun Yat-sen. The 1928 Theses remained policy through the stalinist period, despite the fact that their major premise--that the victory over colonialism could only be achieved if led by proletariat-was contradicted by events such as the independence of India and the rising importance of Africa. Indeed following the Second World War, stalin adopted the doctrine of A. A. Zhdanov that divided the world into two mutually exclusive camps--the communists and the non-communists. This further limited Soviet actions in the third world, which was already moving towards the creation of a neutral third camp. Mirroring the attitudes of America's John Foster Dulles, Stalin urged collective defense and castigated neutralism as "conniving at aggression." 4

The most authoritative statement of late-stalinist theory towards the third world is contained in a 1950 paper by the dean of Soviet Africanists, Ivan I. Potekhin. In it he stated: 
- . the Stalinist theory of the colonial revolution proceeds from the premise that the solution of the colonial problem and the liberation of the oppressed peoples from colonial slavery, is impossible without a proletarian fevolution and the overthrow of imperialism. 5

Therefore in 1950--some thirty years after the revolution--Stalinist theorists were unable to believe that colonialism could be overthrown by the colonial peoples themselves; it could only happen with the overthrow of the imperialist Western nations--by European proletarians. Potekhin pinpointed the reason he felt this was true: the anti-colonial movement was led by the national bourgeoisie, with only a small proletarian element. Every scientific socialist knew "full and final victory of the colonial revolution can be achieved only if and when the proletarian plays a leading role." Ignoring India and Indonesia, he asserted, "the petty-bourgeois nationalist organizations and parties have already proved their incapability of pursuing the course of national 1iberation." 6 In 1954, just one year before he was to play a major part in the reevaluation of this policy, Potekhin again leveled his guns at the national bourgeoisie, attacking the Convention Peoples Party, led by Kwame Nkrumah, because it "reflected the interests of the big national bourgeoisie and did not justify the confidence of the people."7 Seven years later Potekhin would be in the recelving line, congratulating Nkrumah for winning the Lenin Peace Prize. 
In June 1955, Potekhin published an article on the semi-independent Gold Coast (then led by Nkrumah), which moderated the earliest attacks, presaging a change in policy. At the 20th Party Congress in February of 1956, the Party affirmed a change in policy towards an acceptance of "bourgeois nationalism." It appears now that Potekhin and other Soviet Africanists had been quietly lobbying for this for some time. ${ }^{8}$

The change was influenced by three factors, the most important being the death of stalin. It is clear that no reevaluation of policy on this issue could occur while Stalin lived, because he was as much the author of Leninist doctrine on nationalism as Lenin himself. Stalin's theoretical work on bourgeois nationalism was what brought him to the attention of Lenin, well before the Russian Revolution. In his early writings, stalin held that nationalism was anti-socialist because it allowed capitalists to divide the working class along national lines. Only a united internationalist working class could bring about the world revolution envisioned by communists at that time. The example of the First World War, when the socialists of France, England and Germany fought against each other in their respective national armies, appeared to prove that nationalism was antithetical to socialism. After the Revolution, Stalin was elected Commissar for Nationalities and was a major force in the unification of 
the Soviet Union. His main enemies in this endeavor were the "bourgeois nationalists" of Georgia, Poland and the Ukraine. He could not be expected to embrace the same enemy (at least in narrow ideological terms) in Africa. 9 But with Stalin's death, academics were given a great deal more freedom to question what, under Stalin, was unquestionable.

A second factor was the rising importance within Soviet circles of the Soviet Africanists, particularly I. I. Potekhin. Potekhin had faithfully upheld the stalinist theory, while creating institutions for research on Africa which ultimately produced information revealing the weakness of that theory. The death of Stalin opened the door for Africanists to reevaluate theory in the light of new information and for them to have a chance to influence policy. 10 It must be emphasized that while this research was not public, it did circulate freely among the soviet policy elite.

The third and decisive factor was the rise of the influence of the Afro-Asians in world affairs and the nowapparent fact that the struggle against colonialism was coming to fruition with the formerly despised national bourgeoisie at its head. If the Soviet Union did not accept the friendship of the national-bourgeoisie led states, they would have no friends in the Afro-Asian world, and would lose an opportunity to exploit the obvious anti-colonial beliefs of that bloc for its own benefit. 
The change in theory opened new doors for Soviet policy. The new Soviet premier Nikita S. Khrushchev's policy of peaceful co-existence signaled a change towards economic and political (as opposed to military) competition with the West, and Africa was extremely fertile ground, once ideological impediments were removed.

In the period from 1956 to 1961 the Soviets disbursed a significant amount of aid; from July 1959 to July 1961, \$197 million in loans went to five African nations. The motives of the Soviets were political, as one Soviet writer admits:

In its relations with the capitalists the Soviet Union utilizes economic contacts principally as an important lever for . . establishing the desired confidence between states with different social systems.

The tactical change in attitudes toward the national-bourgeoisie, did not mean the abandonment of African communists, to the contrary, Soviet aid usually strengthened pro-Soviet members of nationalist governments. It did mean, however, that good diplomatic relations, not conversion to communism, was to be the controlling factor in Soviet policy.

The rapid increase in Soviet activity in Africa was noticed in the United States, but there was little understanding of the factors behind it. When American commentators saw African nationalists taking Soviet aid, supporting the Eastern Bloc on colonial issues, and criticizing the West, they assumed they were communists. 
What they did not realize was that the Soviets' advantage was due to their having made their peace with the neutralist world--something the United states had yet to do. 
Endnotes

1. I. Potekhin, Sovetskaia etnografia (Moscow) No. 1, 1950, p. 24, cited in Lazar Pistrak, "Communism in Africa: II," Problems of Communism 11 (March-April 1962): 26.

${ }^{2}$ V. I. Lenin, Complete Works (New York: International Publishers), 31:123-27.

${ }^{3}$ The Revolutionary Movement in the Colonies: Theses Adopted by the World Congress of the Communist International (New York: Norker's Library Publishers, 1929), 32.

${ }^{4}$ Dulles borrowed this phrase for a speech of his own on neutralism. (Department of State Bulletin 24 (1950): 726.

5I. I. Potekhin, "Stalin's Theory of Colonial Revolution and the National Liberation Movement in Tropical and South Africa," in The Third World in Soviet Perspective, ed. Thomas Perry Thornton (Princeton, New Jersey: Princeton University Press, 1964), 32.

6 Ibid., 37.

${ }^{7}$ Narody Afriki (Moscow, 1954), 441, cited in Pistrak, 26.

${ }^{8}$ Milton D. Morris, "The Soviet Africa Institute and the Development of African Studies," Journal of Modern African Studies 11 (1971): 247-65.

${ }^{9}$ Robert Tucker, Stalin as Revolutionary, 1879-1929

(New York: W. W. Norton \& Company, 1973). 
10 David Morison, The U.S.S.R. and Africa (London: Oxford University Press, 1964), 59-73.

${ }^{11}$ B. Pichugin, cited in David L. Morison, "Communism in Africa: Moscow's First Steps," Problems of Communism in Africa 10 (November-December 1961): 11-12. 
CHAPTER III

THE UNITED STATES AND AFRICAN NEUTRALISM,

$$
1945-1960
$$

The initial U.S. reaction to the neutralist movement was hostile. The United States was engaged in an attempt to create a system of collective security among Asian nations in the attempt to contain Communism. Neutralism was a direct threat to these efforts. The

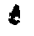
American reaction was capsulized in a 1951 statement by John Foster Dulles, then a consultant to the secretary of state on Asian affairs:

There are some who feel that neutrality is safer than collective security. Neutrality would, of course, be normal if we were living in a world where aggression was permanently banished. But in a world where there are still aggressors, neutfality is no protection, rather it encourages aggression.

When Dulles became Secretary of state in 1953, neutralism was merely an aspect of Asian policy, but over the next seven years neutralism would become the dominant principle of foreign policy for one-third of the world's nations. As the neutralist world expanded, Dulles' rigid opposition became a major obstacle to U.S. relations with this third world. There is evidence that some within the Eisenhower administration understood this reality and had the President's ear. In this prepared statement to the June 6, 1956, news conference, Eisenhower said: 
If you are waging peace, you can't be too particular sometimes about the special attitudes that different countries take. We were a young country once, and our whole policy for the first 150 years was, we were neutral. We constantly asserted we were neutral in the wars of the world and wars of Europe and its antagonism.

Now today there are certain nations that say they are neutral. This doesn't necessarily mean what it is so often interpreted to mean, neutral as between right and wrong or decency and indecency.

They are using the term "neutral" with respect to attachment to military alliances. And may I point out that I cannot see that that is always to the disadvantage of such a country as ours.

The President's remarks caused an immediate uproar in the Department of State. The next day a statement was released to the press, which "clarified" (to the point of contradicting) the President's statement and brought it more into line with the views of the Secretary. The press release stressed that the President did not believe neutralism was suitable in all nations, and that he strongly supported the principle of collective defence treaties which "represent the best and most effective means of preserving world order." It stated further that "the President does believe that there are special conditions which justify political neutrality but that no nation has the right to be indifferent to the fate of another." 3

Dulles further reasserted control over American policy towards neutralism with a speech two days later before the graduating class at Iowa State College. He defended his policy of collective security treaties, calling it a "peace insurance policy": 
These treaties abolish, as between the parties, the principle of neutrality, which pretends that a nation can best gain safety for itself by being indifferent to the fate of others. This has increasingly become an obsolete conception, and except under very exceptional circumstances, it is an immoral and shortsighted conception. The free world today is stronger, and peace is more secure, because so many free nations courageously recognize... . that their own peace and safety would be endangered by assault on freedom elsewhere. ${ }^{4}$

Thus, policy was set back on Dulles' course. Whereas the President's initial remarks implied a general right to neutrality, his later press release only admitted that there are "special circumstances which justify" neutrality. Dulles narrowed those to "exceptional circumstances,' and in a 1957 speech before an Associated Press banquet he denied any justifying circumstances:

Today, nations born to independence are born into a world one part of which is ruled by despotism and the other part which stays free by accepting the concept of interdependence [Dulles' term for the collective security system]. There is no safe middle ground.

International communism is on the prowl to capture those nations whose leaders feel that newly acquired sovereign rights have to be displayed by flouting other independent nations--that kind of sovereignty is suicidal sovereignty. . . .

We want the new independence of others to be something better than a brief twilight preceding the blackout of Communist despotism.

There were three major flaws underlying the Dulles doctrine. First, it rested on the assumption that neutralism was a passive doctrine of indifference, and ignores statements to the contrary by African leaders. Secondly, Dulles did not understand that neutralism did not imply diplomatic equidistance. This caused him to write off 
as communist any nation that refused to support all of the administration's policies. But Dulles' gravest error was a complete underestimation of the ability of African nations and leaders to maintain their independence and freedom of action without getting engulfed by the "black out of Communist despotism." The end result of Dulles' flawed policy was to handicap the United States in its competition with the Soviets, who had already discarded their ideological impediments.

The flaws of the Dulles doctrine were apparent in the administration's actions following Guinean independence. In 1958, French President Charles de Gaulle gave the French West African colonies a choice of remaining within the French Community as autonomous nations or having independence without French aid. The Guinean nationalist leader Sekou Toure convinced the Guinean people to vote for independence. For their ingratitude and as an example to the other states, de Gaulle ordered all French assistance cut off immediately. Records were destroyed and phones ripped from the wall in the exodus of French personnel. The Guineans appealed to the United States, among other western states, for assistance, but Eisenhower refused to upset his fellow general. With little alternative, Toure accepted Soviet assistance. This incident was cited often by critics of Eisenhower's policy. In the 1960 campaign, Kennedy denounced the Republicans charging, "Guinea has moved toward 
the communist bloc because of our neglect." 6

Kennedy was not the only critic of the administration's policy. There was much dissatisfaction with the Dulles anti-neutralist doctrine within Eisenhower's own State Department. Many State Department experts felt the policy was an impediment to countering the aggressive Soviet effort to forge positive and enduring relationships with the non-aligned nations. The United States, they believed, was in danger of permanently identifying itself, in the eyes of Africa, with the hated colonialists.

One of these disaffected officials was Edmond Gullion, veteran Asian expert and friend and advisor to Senator John F. Kennedy; another was Vernon McKay. McKay headed the Africa bureau of the Office of Dependent Area Affairs until September 1956, when he quit to organize a program of African studies at the School of Advanced International Studies at The Johns Hopkins University. In July of 1959 he published a detailed critique of United States policy towards Africa, which among other things criticized the Dulles doctrine on neutralism:

In the political field our most promising opportunity at the moment is to relax pressure on Africans to join the Western camp. Such cliches as the "battle for men's minds" and the "uncommitted nations" have outlived their usefulness. The trouble with the slogan "battle for men's minds" is that it seems to imply that Africans must somehow lose their minds to either the Russian or the American mentality. And that is just what African leaders don't want to do. They want to be distinctively African. The phrase 
"uncommitted nations" is even more outmoded because Africa's made it abundantly clear [at the Accra conference] that they are committed to the neutralist idea of a distinctively African personality making itself felt as a force in world affairs."

He went on to say that the "most we can reasonably hope for . . is neutrality with a Western orientation," and that because of its colonial experience Africa is wary of both Soviet and American pressure. Therefore, "the most influential great power in the new Africa may be the power that succeeds in making its influence and its presence felt in the most unobtrusive manner." 8

McKay's criticisms were echoed in the academic community and by Democratic politicians, many of whom were positioning themselves for the 1960 election. These critics were not only questioning the administration's neutralism policy but the basic tenets of American policy toward Africa.

In 1959, Senator Kennedy's subcommittee on Africa commissioned the Program of African Studies of Northwestern University to prepare a report on Africa, which was written by Program Director Melville J. Herskovits and published on October 1959. The report reflected the views of an emerging academic subdiscipline that was just beginning to establish its identity as such. With the rise of interest in Africa in the late 1950s, and the creation of Area and Language Centers under the National Defense Education Act of 1954, students of Africa began to consider themselves as 
Africanists. In 1957 the African Studies Association was founded. The field was young, exciting and offered young scholars the opportunity to be in the forefront of what appeared to be a major new arena of world politics. Because of the nature of the field, and the rapid decolonization of Africa, early Africanists were very concerned about U.S. foreign policy toward Africa. It was these scholars who contributed to the Herskovits report.

The report surveyed the political and economic c

condition of Africa, drew fifteen sets of conclusions and recommended specific policies to address them. The sets which most concern this study are 2,3 and 4 :

\section{Conclusions}

2. U.S. policy during the past decade has been based on the assumption that Africa, as a continent under the control of our NATO associates, can be given minor consideration.

3. The broadest interests of the United States lie in furthering amicable relations with the peoples and governments of Africa. . .

4. It is important that communism and African nationalism not be confused. The choices that African States will make as regards the world struggle will be influenced
Recommendations

2. The United States must treat Africa, as a major policy area . - on a level with other policy areas, particularly Europe.

3. U.S. policy in Africa must facilitate the implementation of mutual interests with African countries. It should favor their development free from outside interference . . as this is defined in terms of their own values.

4. The United States should recognize that for African states as policy of nonalignment is in the best interestgs of the West and Africa. 
Conclusions

by the use of perceptive insights of African needs cast in African terms...

The conclusions of the Herskovits report were strongly supported by testimony in the hearing which followed its release. Africanists David Apter, Eliot Berg (who later served in the Kennedy Agency for International Development), Rupert Emerson, Ruth Schacter and Immanuel Wallerstein formed the Africa League to present more effectively their case to Congress. Also testifying in support of the report were George Houser, Executive Director of the American Committee on Africa (which was founded in 1953 by white and black liberals to promote United States-African understanding); Wayne Fredericks of the Ford Foundation (Deputy Assistant Secretary for African Affairs, 1961-66); and Taylor Ostrander of American Metal Climax (a corporation with interests in neutralist Ghana and Guinea ). 10

The Eisenhower administration also came under attack by Democratic liberals, especially as the 1960 campaign neared. The earliest political critic was Chester Bowles, a successful advertising executive, who during World War II was the Director of the Office of Price Administration, and who had served as Ambassador to India from 1951 to 1953. After the election of Eisenhower he published his memoirs, wrote a comparative analysis of revolution and lectured. 
One series of lectures was given in April 1956 at the University of California at Berkeley and published as Africa's Challenge to America. ${ }^{11}$ The thesis of Bowles' lectures was that the United States had lost sight of its revolutionary roots in relation to Africa. If its policy towards colonialism did not change, then America was in danger of losing its mantle as the symbol of freedom to the Soviet Union, which was posing as the torchbearer of African freedom. While Bowles did not mention neutralism, he expressed approval of African nationalism and praised the United Nations for providing "a forum in which nationalist aspirations can be expressed." But even more influential than his writings was his active involvement with politics, and the advice he gave to Adlai E. Stevenson and John F. Kennedy. A speechwriter for Stevenson during the 1956 campaign, Bowles was the major foreign policy advisor to Kennedy during his 1960 campaign. After the election he was appointed Undersecretary of State and played a major role in the development of the initial policies towards the third world, as well as the recruitment of energetic and innovative liberals for the State Department and the Foreign Service. 12

Another critic of the administration's policy was Eisenhower's opponent in the 1952 and 1956 presidential elections, former Illinois Governor Adlai E. Stevenson. Stevenson's interest in Africa intensified in the late 
fifties. In 1955 and 1957, he visited Africa, and in May of 1960, he published "The New Africa: A Guide and A Proposal" in Harpers. In this article he argued that the United States had profound interest in preserving good relations with Africa. However, he wrote:

When I speak of maintaining Africa's present Western orientation, I do not have in mind a specific African commitment to support the West in the power conflict. On the contrary, the happiest outcome for both Africa and the West would be if Cold War pressures could be excluded from the African continent altogether. If noninvolvement or neutrality is to be the aid of the New Africa--coupled with determination to keep itself free from any external domination .. that aim is ${ }_{1}$ ertainly compatible with America's hopes and interests. 13

Furthermore, he argues that helping Africa to remain free of the Cold War is "worth many of the billions that could be so easily squandered countering subversion, winning lost ground or fighting wars."14

Thus the 1960 presidential campaign began with a growing climate for change in American policy toward neutralist nations. Significant sectors of the governmental, political and academic establishments were discussing a re-evaluation of policy. Into this debate stepped presidential aspirant John F. Kennedy. 
Endnotes

1 John Foster Dulles, "Peace without Fear," Department of State Bulletin 24 (1951): 726 .

${ }^{2}$ U.S., President, Public Papers of the Presidents of the United States (Washington, D.C.: Office of the Federal Register, National Archives and Records Service, 1953- ), Dwight D. Eisenhower, 1956, 554-55.

${ }^{3}$ Department of State Bulletin 29 (June 18, 1956): 1001 .

${ }^{4}$ Dulles, "The Cost of Peace," Department of State Bulletin 29 (June 18, 1956): 999.

${ }^{5}$ Dulles, "Dynamic Peace," Department of State 41 (May 6, 1957): 716 .

${ }^{6}$ Arthur M. Schlesinger, A Thousand Days (New York: Harper \& Row, 1965), 568; William Attwood, The Reds and the Black (New York: Harper \& Row, 1967).

7McKay, "A United States Policy for the New Africa," Current History 38 (July 1959): 3 .

8 Ibid.

${ }^{9}$ U.S. Congress, Senate, Committee on Foreign Relations, Subcommittee on Africa, Africa, A Study Prepared by Programs of African Studies, Northwestern University. 86 th Cong., 1st sess., 1959, 73-77.

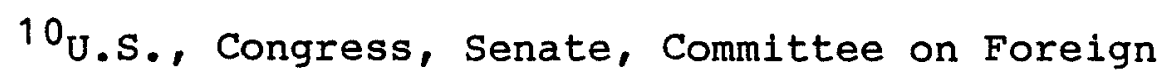
Relations, Subcommittee on Africa, Hearings Before the 
Committee on Foreign Relations, Part 1, 86th Cong., 2d sess., 1960.

11 Chester Bowles, Ambassador's Report (New York: Harper \& Brothers, 1953); The New Dimensions of Peace (New York: Harper \& Brothers, 1954); Africa's Challenge to America (Berkeley: University of California Press, 1956). 12 Bowles, Promises to Keep: My Years in Public Life, 1941-1969 (New York: Harper \& Row, 1969).

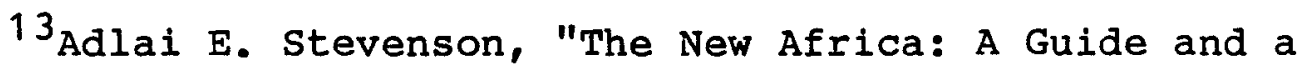
Proposal," Harpers 220 (May 1960): 48.

${ }^{14}$ Ibid., 54 . 


\section{CHAPTER IV}

THE NEW FRONTIER AND NEUTRALIST AFRICA

By temperament, ability and experience, the politician most able to grasp the historical forces that were challenging U.S. foreign policy was John F. Kennedy. From the beginning of his political career, Kennedy had been interested in the third world. In 1951, he visited the Far East and on his return denounced western colonialism (particularly in French Indochina) on the floor of the House. ${ }^{1}$ As a freshman senator in July of 1953, he sought to amend the Mutual Security bill, to provide that funds "be administered in such a way to encourage... the independence desired by the Associated States [Vietnam, Laos, Cambodia]."2 In April 1954, he gave a major speech warning against U.S. intervention to save the French from being defeated at Dien Bien Phu, and again he called for independence--stopping short of demanding French withdrawal. Kennedy's African education began in early 1957 when he met with Habib Bourguiba, Jr., the son of the president of Tunisia, and Mongi Slim, Tunisia's ambassador to the United States. Joined by the Algerian National Front's Washington representative Abdekader Chanderli, the North Africans educated Kennedy on the complex history of the Algerian war for independence from France, and won him over to their cause. ${ }^{3}$ 
In the summer of 1957, he gave two major speeches in which he criticized the Eisenhower administration for its blind support of French colonialism:

The single most important test of American foreign policy today is how we meet the challenge of imperialism, what we do to further man's desire to be free. On this test more than any other, this nation will be critically judged by the uncommitted millions in Asia and Africa . . [United States support for France] has furnished powerful ammunition to anti-Western propagandists . . . and will be the most troublesome item facing the October conference in Accra of the free nations of Africa, who hope by easing the transition to independence of other African colonies, to seek common paths by which that great continent can remain aligned with the West. 4

Kennedy's speech was severely criticized by the New York Times, which said he "added fuel to a raging fire," and to a lesser degree by Eleanor Roosevelt and Adlai Stevenson. But the harshest attack came from Truman's former Secretary of State Dean Acheson, who characterized the speech as rash and naive. French opinion was divided along political lines with criticism from the pro-government papers, and favorable editorials in L'Express and other papers opposed to the war. 5

The reputation Kennedy gained from his interest in Algeria and Africa made him a natural candidate to chair the African subcommittee created by the Senate Foreign Relations Committee in 1958. Kennedy and his colleagues on the subcommittee, Mike Mansfield, Frank Church and Albert Gore, held hearings that year on Africa in which America's foremost Africanists testified. In June of 1959, Kennedy 
delivered a speech before the Second Annual Conference of the American Society of African Culture. He began with a knowledgeable exposition of the problems of modern Africa and then turned to the question of America's interests in Africa. "Our goal, for the good of the West, is a strong Africa," he said; "And no people can become strong in a climate of servitude and social indignity. What can the United State do?" Primarily, he noted, the United States could increase aid through the Mutual Security Program and an expanded Development Loan Fund. "While the benefits to our national security from a new approach to Africa cannot be overlooked," Kennedy concluded; "Let us never assist Africa merely because we are afraid of Russian assistance in Africa. Let us never convince the people of that continent that we are interested in them only as pawns in the cold War." 6 To sharpen his knowledge of African affairs, Kennedy met with several African leaders, including Telli Diallo and Alex Quaison-Sackey, the UN Ambassadors of Guinea and Ghana respectively. On November 1, 1959, he met with Guinean President Sekou Toure at Disneyland. The meeting is recounted by the U.S. Ambassador to Guinea, John Morrow, who was present:

Senator Kennedy then expressed his keen interest in Guinean independence and in the struggle confronting Toure to maintain this independence. Turning to me, he said that, with all due respect to me and the party which I represented, he would like to go on the record as assuring President Toure that, if the Democratic Party came into power in the 1960 election, it would 
have a great interest in the progress of Guinea and other emerging nations of Africa.

At that time, Toure expressed his admiration for Kennedy's stand on Algerian independence, a remark Kennedy was to hear echoed in many of his meetings with Africans before and after his election.

In August of 1960, Kennedy had frank discussions of Africa's economic problems with K. A. Gbedemah, Ghanaian Minister of Economy. 8

Toward the end of 1959 , Kennedy began preparations for his run for the presidency in 1960. In February 1960, Kennedy persuaded Stevenson loyalist and liberal theorist Chester Bowles to serve as his foreign policy advisor.

As early as November 1959, Kennedy began to criticize Eisenhower's policies toward the third world. He decried the "eight gray years . . that the locusts have eaten" and attacked several areas where he felt the administration had allowed United States prestige and interests to deteriorate. One of the areas was foreign policy, and Kennedy criticized Eisenhower for not countering Soviet aid policy vigorously enough. "When we abruptly abandoned the Aswan Dam in Egypt . . the Russians went ahead to finance it," he said, "while we starve the Development loan Fund . . the Sino-Soviet bloc has already passed us in economic assistance to selected key areas." 9 
In June of 1960 , just before the Democratic convention, Kennedy released a major position paper on foreign policy, outlining a twelve-point agenda, two of which are relevant to this study. One point called for an increase in the flow of capital from the west to the third world to frustrate Communist policy and "[enable] emerging nations to achieve economic as well as political independence." The other dealt with Africa:

We must greatly increase our efforts to encourage the newly emerging nations of Africa--to persuade them that they do not have to turn to Moscow--to help them achieve the economic progress on which the welfare of their people and ability to resist Communist subversion depend. 10

After Kennedy's election he immediately created a number of task forces to study possible policy directions. The Task Force on Africa was headed by political scientist Robert C. Good, who had written an article in 1960 that questioned the characterization of Guinea's Sekou Toure as a communist. For Good, Toure, like his fellow African leaders, was primarily an African nationalist, and "he knows that his ambitions as an African leader are forfeited the moment Guinea loses all initiative of action to the East."11 The Task Force's final report supported non-alignment and suggested that the United States should "respond affirmatively to reasonable aid requests, but opposed using aid as political bribery for cold war purposes. . . ." It stressed that U.S. policy in Africa should be "low-key and 
practical and in harmony with the wishes of Africa's own nationalist leaders."12

The President's Inaugural Address incorporated the new change in policy. Kennedy evoked the Bowles theme of the United States as the first revolutionary state and then sent his message to Africa:

To those new states whom we welcome to the ranks of the free, we pledge our word that one form of control shall not have passed away merely to be replaced by a far more iron tyranny. We shall not always expect to find them supporting our view. But we shall always hope to find them strongly supporting their own freedom--and to remember that, in the past, those who foolishly sought power by riding the back of the tiger ended up inside.

To those peoples in the huts and villages of half the globe struggling to break the bonds of mass misery, we pledge our best efforts to help them help themselves, for whatever period is required--not because the communists may be doing it, not, because we seek their votes, but because it is right.

The commitment to tolerance of neutralism was expanded and elaborated in a speech by the U.S. observer to the Economic Commission on Africa, Walter Kotschnig, in which he told his African audience that the basic tenets of United States policy were a wish to see Africa "grow and prosper" in freedom, a conviction not to "impose our own views and ways of life on Africa," and the desire "to do everything possible to keep the cold war out of Africa." Then Kotschnig outlined the economic aspects of the new tolerance:

We have provided substantial and practical help to Africa and shall continue to provide aid without any strings attached... . 
I want to stress that we do not want to impose our own socio-economic system on countries which seek our help. . . we fully recognize the importance of the public sector $\cdot 14^{\circ}$ in newly developing countries.

This was an important change in American policy because many African economies were public-sector dominant and the Eisenhower administration had refused to assist the public sector, in effect denying many nations aid. The conservative economists in the administration believed such assistance fostered socialism. Africans, however, believed the United states was trying to impose its own economic theories on them--theories that were profoundly out of touch with African realities. This new, more realistic, policy put the Kennedy administration on even footing with the USSR, which had been giving state-to-state economic aid with considerable political benefit.

One problem with the no-strings aid policy was selling it to a Congress that was usually unwilling to appropriate foreign aid unless it was justified in terms of national security. The administration had to make this connection if it hoped to pass the Foreign Aid Act of 1962 . In a major policy speech on foreign aid given in May of 1961. Undersecretary of state Chester Bowles defended the no-strings aid policy as an anti-communist measure. He began by describing how the Communists were now in a "total' offensive against the West, which had shifted from the military to the economic sphere. He then ridiculed the 
previous way of dealing with it, which was "piece-meal" assistance to nations that had "the noisiest Communists" and only limited aid to others. Such an approach tended to convert local communism into a sort of "natural resource." Furthermore, this policy put the United States in an "eternally defensive position," always reacting to soviet actions, with no constructive policy of its own. The other alternative was to use the resources of the West to help the underdeveloped world to create a way of life that makes Marxism irrelevant. Bowles described a "world revolution" for independence, nationalism and dignity:

Let us make it clear that our assistance program are not designed to check or divert the world revolution - . we have no such desire. Our purpose is to help this revolution achieve its true goals because we know that such a development will contribute to our own security and well-being. . . . We have no intention of attaching political strings to our aid, of requiring countries to support U.S. policies as a condition to receiving aid.

Bowles concluded by linking the "fate of America" with the "fate of the billion and a half people" living in the underdeveloped world. "Our survival no longer depends on guns and tanks and bombs alone," he said. It depended, he continued, on the price of rice in southeast Asia, the dignity of a citizen in the Congo, and the security of a West Berliner. "The struggle for human freedom cannot be compartmentalized."16

The success of the new policy would depend on the quality and inclinations of the people appointed to carry it 
out. The first foreign policy appointment, that of G. Mennen Williams as Assistant Secretary of State for African Affairs, was a positive signal. Williams, the progressive governor of Michigan and proponent of civil rights, had at a crucial point in the Democratic Convention pledged the delegates he controlled to Kennedy. Arthur M. Schlesinger, Jr., describes him as having a "clear and strong vision of the American role as a friend of African independence and development," but faults him for not being t "too proficient in the intramural warfare of the Department of State." But Kennedy and Williams were of the same mind on Africa, and "when problems made their painful climb through bureaucratic conflicts, Kennedy ordinarily decided them Williams' way."17

The most important foreign policy position was that of Secretary of State. Kennedy was slow to fill this position, in large part because of the political campaigning by Adlai Stevenson's supporters who felt he was owed it for his service to the Party. But Kennedy felt that stevenson was too indecisive and offered him the UN ambassadorship at cabinet rank. Senator William Fulbright was closely considered, but his segregationist record did not fit with a pro-African policy. The decision came between Chester Bowles, to whom Kennedy was obligated for his advice and support during the campaign, and Dean Rusk, who had wide experience in State under Truman, working on the Marshal 
Plan and NATO, and serving as Assistant Secretary of State for Far Eastern Affairs during the Korean War. He was now the President of the Rockefeller Foundation. Despite Bowles' greater affinity with Kennedy's views on the underdeveloped world, he was rejected for Rusk because of his lack of experience in European affairs. ${ }^{18}$ This was to prove to be a serious blow to Kennedy's African policy. Bowles wished to implement a dramatic shift in foreign policy as outlined by Kennedy in his campaign--by reorganizing the State Department to give greater policymaking powers to the geographic bureaus. Rusk, on the other hand, was a Europeanist and decidedly unsympathetic to the policy of tolerating neutralism. (Bowles remembers his horror at a conversation concerning neutralists in the UN in which Rusk said, "It is high time that they decided what side of the cold war they are on." $)^{19}$

Bowles was given the undersecretariat, but was flanked by Rusk's men at the Bureaus of Economic Affairs (headed by George Ball) and Political Affairs (headed by George McGhee, a conservative Democrat who had served as Eisenhower's Assistant Secretary for African Affairs).

Once installed, conflict between Rusk and Bowles began. Bowles brought new faces into state and wrote memos on reorganizing the state Department, and frequently went over Rusk's head to Kennedy with suggestions. Rusk resented being passed over, disagreed with Bowles' assessments on 
reorganizing the State Department, and distrusted the liberals Bowles was inviting into the Department. After the Bay of Pigs fiasco, Rusk sought to take the heat off himself by leaking rumors of their disagreements to the press. Bowles was unfairly kept in the dark about his status until November 1961, when Kennedy announced the shake-up known as the "Thursday Night Massacre." Chester Bowles was removed from his post as Undersecretary and was appointed the President's Special Representative and Advisor on African, Asian, and Latin American Affairs, a position with perks (higher salary and ambassadorial status) but no power. Bowles was replaced by George Ball. McGhee replaced Ball, and Walt Rostow came over to become the Assistant Secretary for an expanded Policy Planning Office. 20 The shake-up signaled the triumph of the Rusk-Acheson forces over the Bowles-Stevenson group. Williams at the African Bureau lost in Bowles his major ally in the Department of state. However, Williams still had the support of Kennedy and had attracted the attention of everyone with the way he took charge of the African Bureau and inspired his staff. The implementation by the Kennedy administration of the new posture toward neutralism began immediately. Overtures were made to prominent leaders of the non-aligned movement, such as Nehru and Nasser. Kennedy also took a strong early position against apartheid in Rhodesia and South Africa, which indicated to African neutralists that a 
real change in American policy may have been occurring. The one nation in Africa that seemed most unlikely to accept this new American president was the former French colony of Guinea. At the time kennedy took office, relations were extremely tense. Guinean President Sekou Toure accused him of complicity in Patrice Lumumba's death (despite the fact that he had been killed two days before Kennedy's inauguration), and in April Toure accepted the Lenin Peace Prize. Still Kennedy continued to regard Toure (whom he had met in 1959) as an independent nationalist. He chose William Attwood, ex-reporter for Look and one of the Stevenson people recruited by Bowles, for the position of Ambassador to Guinea. 21 Attwood was young and energetic and impressed Toure with his shirt-sleeve style. Attwood reported back on the confused Russian aid program, which he called "Malice in Blunderland" and the numerous Russian faux pas. Sensing an opportunity to capitalize on Soviet mistakes, Attwood urged an aid program to show American faith. Philip Habib was sent by AID to help put together a small aid program (about $\$ 25$ million), which they submitted in May 1961 where it immediately became stalled in bureaucracy. Attwood and Habib flew to Washington and began personally to lobby key individuals, particularly Attorney General Robert Kennedy, who had just returned from visiting Africa and was immediately sold on the plan. After a talk with the president the plan began to move through the 
bureaucracy. 22

The rapprochement bore fruit when in November 1961

Toure expelled Soviet Ambassador Daniel Solod, claiming that he was involved in a plot against Toure. He also purged from his Party members he felt were too pro-Soviet. A visit by Deputy Premier Anastas Mikoyan did not heal the wound-Toure refused to see him. 23

Attwood exploited the Soviet/Guinea tensions to improve the Guinea rapprochement with the West. In 1962, the promised aid arrived and relations began to warm considerably. In October, Toure met Kennedy at the While House and was impressed by his hospitality, quite in contrast to the cool reception he had received in 1959. During the Cuban missile crisis, Toure refused to allow Soviet planes to refuel in the Soviet-developed airport at Conakry. When Attwood returned to Washington in 1963, he was able to report Toure had given him a warm send off, at which he had said:

Every African leader guided by a conscience must recognize now the value cooperation with the United States and that American assistance is, contrary to what we are told, the most disinterested, the most effective and the most responsive to our real needs.

The policy statements of Kennedy and his administration, the selection of G. Mennen Williams to head the African Bureau, and the initial reports of Bill

Attwood's tour in Guinea were all signs that American policy was moving toward tolerance of neutralism. However, the 
selection of Dean Rusk as Secretary of State and the later demotion of Chester Bowles suggested the limits of change in foreign policy still defined by the cold war. These conflicting forces of change and inertia would shape the debate over the new policy in its first major test: The decision whether or not to assist in the Ghanaian Volta Dam project. 
Endnotes

${ }^{1}$ Herbert S. Parmet, Jack: The Struggles of John F.

Kennedy (New York: Harper \& Row, 1980), 226-28.

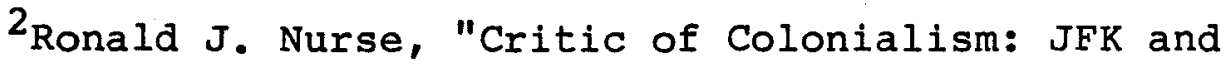
Algerian Independence," The Historian 44 (February 1977): 308 .

${ }^{3}$ Alistair Horne, A Savage War of Peace: Algeria, 19541962 (New York: Penguin Books, 1977), pp. 246-47.

${ }^{4}$ Speech given July 2 and July 8, 1957, in John F. Kennedy, The Strategy of Peace (New York: Harper \& Row, 1961), pp. 65-81).

${ }^{5}$ For reaction, see Nurse, 318; Parmet, 407; New York Times, 3 July 1957, sec. 1, p. 1 .

${ }^{6}$ Summary Report, Second Annual Conference, American Society of African Culture, New York, June 26-29, 1959, $8-10$.

7 John H. Morrow, First American Ambassador to Guinea

(New Brunswick: Rutgers University Press, 1968), 106-7.

${ }^{8}$ New York Times 16 August 1960, sec. 1, p. 2.

${ }^{9}$ Kennedy, 197.

10 Ibid., ix.

11 Robert C. Good, "Why Guinea Looks East," New Republic 142 (June 13, 1960): 10-12.

12 William Attwood, The Reds and the Blacks: A Personal Adventure (New York: Harper \& Row, 1967), 15. Attwood gives 
a brief synopsis of this report.

13 U.S., President, Public Papers of the Presidents of the United States, Washington D.C.: Office of the Federal Register, National Archives and REcords Service, 1961- ), John F. Kennedy, 1961, 1.

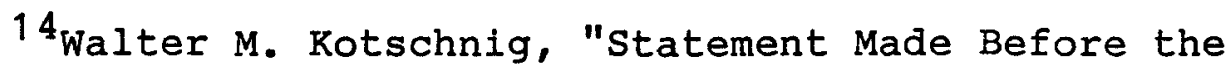
Third Session of the Economic Commission for Africa, held at Addis Ababa, Ethiopia, Feb. 6-7," Department of State Bulletin (March 13, 1961): 376-78.

15 Chester Bowles, "Foreign Aid: The Decision of the Sixties," Department of State Bulletin (May 15, 1961): 706. 16 Ibid., 709.

${ }^{17}$ Schlesinger, 555-56.

18 Schlesinger, 138-41.

${ }^{19}$ Chester Bowles, Promises to Keep: My Years in Public Life, 1941-1969 (New York: Harper and Row, 1971), 359. ${ }^{20}$ For varying accounts of the events leading up to the "Thursday night massacre," see Bowles, Promises, 285-368; Roger Hilsman, To Move a Nation: The Politics of Foreign Policy in the Administration of John F. Kennedy (New York: Delta, 1967), 17-21.

21 Attwood, 1-44.

22 Ronald w. Walters, "Formulation of United States Policy Toward Africa, 1958-1963" (Ph.D. diss., The American University, 1971), 392. 23 Ibid., 395. 
24 Attwood, 131; R. W. Howe, Along the Afric Shore

(Westport, CN: Greenwood Press, 1975), 143. 


\section{CHAPTER V \\ KWAME NKRUMAH AND GHANA'S \\ INDEPENDENCE STRUGGLE}

Because of its relatively early independence, its political sophistication and the dynamism of its leadership, by 1961 Ghana was Africa's premier nation-state in the eyes of the international community. President Kwame Nkrumah and many of his advisors had been educated abroad, had participated in the international anti-colonial and panAfricanist movements, and in general were an outward looking group. By the time John F. Kennedy took office, most of the international community of Africa and Asia knew of the Ghanaian government's Volta Dam project and of the Eisenhower administration's reluctance to support it. They were also aware of President John F. Kennedy's pledge to tolerate neutralism and to not tie strings on American assistance in the economic development of Africa.

It soon became apparent that the question of whether or not the United States would support and assist in the Volta Dam project would be a litmus test on Kennedy's policy toward African neutralism. If he assisted the project, despite the avowed neutralism of Ghanaian foreign policy, it would be a positive step forward for U.S. policy--a step which many believed would erase some of the ground grained 
by Soviet policy over the last five years. However, if Kennedy let ideological and foreign policy differences with Ghana get in the way of American assistance, then the loss to American prestige and goodwill in Africa could be irreparable.

To understand the dynamics of Ghana's foreign policy and the political view of its leadership, one has to understand the history of Ghana's independence struggle. While John F. Kennedy was organizing his fellow war veterans for a campaign for the U.S. Congress, Kwame Nkrumah was planning boycotts and strikes against the British colonial government, and spending time in colonial prisons. Just as Kennedy's generation was shaped by World War II and the New Deal, Nkrumah's was molded by the anti-colonial struggle and dreams of pan-African unity.

The World War that launched John F. Kennedy's career set into motion forces that would soon lead to the end of the European colonial empires and the emergence of an independent Asia and Africa. The process began in 1947, when war-wearied Britain gave in to the Indian peoples' demand for independence. India's attainment of independence through peaceful means had a significant impact on Britain's African colonies. Africa nationalists saw an example in the use of Gandhian nonviolence, and they perceived that the British imperial idea was in its decline and that the British colonial policies were beginning to take into 
account the eventual dissolution of the Empire. Of all the African colonies, the Gold Coast (Ghana), by way of its economic, educational, as well as political advancement, was the most prepared to take advantage of the opportunity the Indian example presented.

Since 1918, when Gold Coast attorney J. E. Casely Hayford founded the National Congress of British West Africa, the colony had been a center of anti-colonial organization. During the 1920 s and 1930 s nationalist sentiment was expressed through the West African student's Union and the Pan-African congresses organized by the American W. E. B. Dubois. In 1935 Nigerian Nnamdi Azikiwe arranged to have eight Nigerian and four Gold Coast students sent to America for further education. 1

Among those students was Kwame Nkrumah, son of an Nzima goldsmith, educated at a Roman Catholic mission and the prestigious Achimota secondary school. Nkrumah enrolled at Lincoln University in Pennsylvania, where he remained until 1945, obtaining advanced degrees in theology, education, and philosophy. While in the United States, Nkrumah also taught, but most of his time was taken up with political activities. ${ }^{2}$

Nkrumah left America in 1945 for London to join in the preparation of the Fifth Pan-African Congress to be held in Manchester. He was elected general secretary of the West African National Secretariat established by the congress, 
and became the editor of its organ, the New African. In 1947 Nkrumah was offered the position of party general secretary by Dr. Joseph B. Danquah, leader of the recently founded United Gold Coast Convention (UGCC). The UGCC was a small conservative party of barristers, merchants, farmers, and chiefs, and its leaders wanted Nkrumah to build a mass party. Nkrumah returned home in December 1947, resolved to do just that; however he had no intention of turning this mass movement over to the conservative UGCC. ${ }^{3}$

In early 1948, Nkrumah and five other UGCC officials were arrested for alleged complicity in February riots by ex-servicemen and were detained at Kumasi. Meanwhile, Governor Sir Gerald Creasy established a commission to investigate the riots and the UGCC. The Commission recommended that a new constitution should be drawn up with the aid of moderate African leaders. 4 After his release, Nkrumah founded the Accra Evening News as the organ of a radical vanguard within the UGCC, which soon relieved him of his position as general secretary. ${ }^{5}$ Nkrumah then split with the UGCC, founded the Convention People's Party, and captured most of the UGCC rank and file membership. The CPP's program called for immediate selfgovernment to be attained by "legitimate political agitation, newspaper and educational campaigns and as a last resort the constitutional application of strikes, boycotts, and noncooperation based on the principle of absolute 
nonviolence." 6

Meanwhile, that year the commission of Britons and Africans (most drawn from the UGCC) released the new constitution, which was immediately implemented by the new Governor Charles Arden-Clarke. It called for a directly elected all-African Legislative Assembly, an Executive Council with eight African ministers from the Assembly, and three ministers appointed by the Governor, who also retained all defense and external powers. The CPP denounced the new constitution as a subterfúge and began a campaign of "Positive Action" to force the British to accede to immediate self government. Strikes and boycotts were called and the Government responded by arresting and convicting Nkrumah and other CPP leaders of incitement, libel, and sedition. K. A. Gbedemah, the CPP general secretary, kept the movement alive, and the CPP won a majority of seats in the February 1951 election of the Legislative Assembly. Arden-Clarke released Nkrumah and asked him to form a "government."7

For the next six years, Nkrumah and Arden-Clarke would cooperate to achieve a peaceful and orderly transition to independence. As Prime Minister of a self-governing British colony Nkrumah could exert real power on the domestic level, while in international affairs he was restrained by the fact that Britain retained all official defense and foreign policy powers and that the Gold Coast 
was not a sovereign state. Thus restrained, Nkrumah plunged into establishing the supremacy of the CPP, Africanizing the civil service, and planning the economic development of his nation. The CPP built an impressive machine, garnering large majorities in the 1954 and 1956 elections. Nkrumah's five-year plan was implemented. One of the major parts of the plan was the Volta River project, an old British plan to develop the hydroelectric potential of the Volta River to aid the processing of bauxite mined nearby. The CPP had embraced the project as a campaign promise in the 1951 election, and it was the foundation of its program of industrialization. 8 
Endnotes

${ }^{1}$ Winston Lee Kinsey, "The United States and Ghana, 1951-1966" (Ph.D. diss. Texas Tech University, 1969), 1-3.

2 Ibid., 5-6.

3 Ibid., 8-11.

${ }^{4}$ Ibid., 11-12.

${ }^{5}$ Ibid., 12-13.

$6_{\text {Kwame Nkrumah, Ghana: The Autobiography of Kwame }}$

Nkrumah (New York: International Publishers, 1957), 111-12.

${ }^{7}$ Kinsey, 14-16.

Ibid., 270-73. 
CHAPTER VI

ORIGINS OF GHANAIAN FOREIGN POLICY

The lack of external powers did not keep Nkrumah from planning for Ghana's post-independence diplomacy, or from forming the nucleus of a foreign policy establishment. In June 1954, Nkrumah created the Governor's Advisory Committee on Defense Powers (GACDP) to assist in the preparation of foreign policy machinery for Ghana's eventual entry into international politics. The members were chosen from the nationalist elite which made up the inner circle of CPP power. K. A. Gbedemah, the businessman who had led the party to victory in the 1951 elections while Nkrumah was jailed, was now an extremely competent minister of finance (1954-1961), the Colonial Office's advisor to the British UN mission, and a strong proponent of attracting foreign investment and the development of the Volta Dam project. Kojo Botsio had wide experience in the Pan-African movement of the 1930 s and 1940 s, and was to represent the Gold Coast in 1955 at the Bandung conference of Asian and African Peoples. Like Gbedemah, he was prominent in business, and his wife was "one of the most important traders in Ghana." In contrast, Ako Adjei was a Marxist, the "most radical (and least influential) of the inner elite," who played a part in Nkrumah's appointment as UGCC secretary-general in 1947. He acted as a roving ambassador on various missions until his 
appointment as foreign minister in 1959.1

One of the first actions of the GACDP was to establish a foreign service drawn from the senior levels of the civil service. Most prominent of these men were $F . S$. Arkhurst (minister to the UN, 1957-62 and Principal Secretary, Ministry of Foreign Affairs, 1962-1965); A. L. Adu (Principal Secretary, MFA, 1957-1959); F. E. Boaten (first minister to the USSR, 1960-1961); and Alexander Quaison-Sackey (Ambassador to the UN, 1959-65; President of 19th Session of the UN Gefferal Assembly; Foreign Minister, 1965-1966). They were sent to London for training at the British Foreign Office, and later on to British missions around the world to gain practical experience. This British training would always make the group questionable in the eyes of their radical rivals. 2

In addition to GACDP and the foreign service, Nkrumah's various expatriate advisors influenced early Ghanaian policy. Preeminant among them was the West Indian journalist, George Padmore. Padmore had been one of the major figures in the organized Pan-African movement since the nineteen twenties. He first met Nkrumah in 1945 in London, and the two men worked closely to prepare for the Fifth Pan-African Congress and later within the West African Secretariat. After coming to power, Nkrumah invited Padmore to the Gold coast where he immediately began to exert a powerful role on foreign affairs. To Padmore, Ghana was 
merely a stepping-stone to the greater goal of a unified African continent. This idea became a major aspect of Ghanaian policy. Another area where Padmore's influence was evident was in the Ghanaian confidence in conference diplomacy. The organizational expertise that Nkrumah and Padmore brought to this form of diplomacy from their experience in the Pan-African Congress movement gave Ghana exaggerated power in African affairs. 3

A very different foreign advisor was the Australian Sir Robert Jackson. Once an assistant secretary-general of the UN, Jackson had given advice to the Indian and Pakistan governments, before he was invited to the Gold Coast in 1953 to study the Volta River Project. His report of 1956 confirmed the feasibility of the project, and he served from then until 1961 as chairman of the development commission charged with drawing up a plan acceptable to foreign investors. Jackson and his wife, Barbara Ward (a prominent American development economist who was a friend of Kennedy and many of his academic advisors) played a restraining role and served as a bridge between Nkrumah and the Kennedy administration. Their influence was mainly directed at convincing Nkrumah that it was in Ghana's best interest to maintain the good relations with the west that were vital to the attraction of private investment in the Volta River project and other programs. 4 
The most important policymaker was Nkrumah himself. A complex man, he has been often maligned and subject to pseudo-psychological analysis by the westerners who have written about him. Until 1988, there was no scholarly biography of Nkrumah based on archival, as opposed to anecdotal, sources.

Among his critics, Henry L. Bretton describes Nkrumah as an intellectually average man, easily manipulated and flattered by his leftist expatriate advisors, whose earlier Pan-African militancy "gradually deteriorated into a form of escape exhilarating and psychologically more rewarding than the drudgery of ever more disappointing experiences at home." He argues that after a 1962 attempt on his life, Nkrumah became superstitious and obsessed with security. 5

W. Scott Thompson sees Nkrumah's years in America as being crucial in his development of the "Wilsonian strand of utopianism" characteristic in Nkrumah's "obsession" with African unity. Thompson describes a love-hate relationship between Nkrumah and the West, reflected in his use of western advisors and his deference to the Queen. "Royal favor, or gestures from the White House, easily influenced Nkrumah, because of his awe for the very Western power power he wished to displace." 6

Nkrumah's biographer David Rooney has perhaps the most balanced view of Nkrumah. Nkrumah is portrayed as a 
visionary who "almost alone among African leaders, saw the continent's future in a global perspective." The Marxist analysis he absorbed in the United States led him toward a vision of a "united and self-sufficient Africa." Rooney writes: "Through the Volta river project, he set out to make Ghana the industrial base for the whole of Africa, and to save the continent from the debt creating intentions of the western world."

Nkrumah failed in bringing about his vision, Rooney argues, because it was "a task too big for one man." His inability to conquer corruption and establish a stable regime in his own country made the realization of his continental ambitions impossible. Nkrumah "saw all the visions, dreamt all the dreams, and made all the mistakes." But Nkrumah's mistakes were almost inevitable, Rooney concludes, given the size of his dreams and an overwhelming legacy of colonialism, poverty, debt and dependency. 7

The most important aspect of Nkrumah's personality, most observers of Nkrumah believe, was what Robert Jackson called the "separate sealed compartments in his mind," which enabled him to satisfy both his Western and Eastern suitors. This ability helped Nkrumah to play both cold war powers off in his attempts to obtain development aid for his country. As David Williams, the editor of West Africa and a close observer of Nkrumah, has noted: "Nkrumah was convinced he would have to be the perfect 'neo-colonialist' leader to get 
Western investment. . . And he had an image of exactly how he would have to behave to preserve their support." 8

In the Ghanaian foreign policy establishment, there were several strains which would later cause major disputes. There were ideological conflicts between the pro-Western officials, such as Gbedemah, and the more radical leftists over the relations with the West. In addition there were disputes between the militant pan-Africanist theorists and the young diplomats trained in more realistic policy concerns. Nevertheless, on the eve of independence there was a consensus on basic policy. It was a policy of vigorous pan-Africanist diplomacy and positive neutralism (with a subtle tilt toward the West), the initial objective of which was the acquisition of foreign investment for the Volta River project. It was a policy of many contradictions. Pan-Africanist doctrine was anti-colonial and anti-imperialist, calling for opposition to many American policies. Neutralism implied real non-alignment, and Nkrumah's Volta project could only be funded by massive Western aid. Still, Nkrumah was able, initially at least, to reconcile these contradictions because Western aid was vital to his immediate plans. 
Endnotes

${ }^{1}$ W. Scott Thompson, Ghana's Foreign Policy, 1957-1966: Diplomacy, Ideology and the New state (Princeton: Princeton University Press, 1969), 17-20.

2 Ibid., 19.

3 Ibid. , 21-23.

${ }^{4}$ Ibid. , 21.

${ }^{5}$ Henry L. Bretton, The Rise and Fall of Kwame Nkrumah (New York: Praeger, 1972), 29.

6 Thompson, 25 .

${ }^{7}$ David Rooney, Kwame Nkrumah: The Political Kingdom in the Third World (New York: St. Martin's Press, 1988), 2. 8 Thompson, 27. 
CHAPTER VII

GHANA AND THE EISENHOWER ADMINISTRATION, $1957-1960$

Ghana's independence ceremonies were attended by representatives of nearly seventy nations; among them were those of the Unite States and the Soviet Union. On May 3, 1957, Vice President Richard Nixon arrived and was greeted at the airport by Prime Minister Nkrumah and by thousands shouting "freedom! freedom!" and waving the new red, gold and green flag of Ghana. ${ }^{1}$ The next day, Nixon met with Nkrumah and his foreign minister, A. L. Adu, at the American Consulate General for discussions which would set the tone for Ghanaian policy for the next three years. Both men had hidden agendas. Nkrumah wished to move the discussion from generalities to questions of the Volta Dam, while Nixon was concerned with Nkrumah's expressed policy of neutralism and wished to extract assurances that Ghana would not deviate from its western alignment.

After explaining his country's efforts to diversify its economy, Nkrumah guided the conversation to the Volta River project, explaining the efforts to finance it. Nixon "listened sympathetically," but made no commitments, merely stating that it was a "matter for exploration" and then shifting the subject to desirability of private investment. 
Nixon then turned to the subject of postindependence Ghanaian foreign policy. He inquired whether he might refer to Ghana's policy as "nationalist," saying that he disliked the term neutralism, since it implied moral neutrality and a lack of concern about preserving Ghana's independence. Nkrumah fell into Nixon's trap, stating that Ghana's policy "will be one of non-involvement and nonalignment in the East-West struggle. 'But,' he said, 'Ghana can never be neutral.' It will jealously safeguard its independence and resist all efforts at domination." 2

Within the context, Nkrumah's remarks indicated that Ghana would be non-aligned, but Nixon informed the press afterward that Nkrumah had said that "Ghana will never be neutral" in the "cold war,"3 a clear distortion. Nixon's report to the President on his return would not have pleased Nkrumah either. Nixon gave lukewarm support to the Volta scheme. Noting the cost of the project was "formidable," he suggested that America "follow closely the scheme with a view toward ascertaining whether it is a well-conceived and practical project, which we should support in the IBRD [World Bank] and perhaps aid to a limited extent ourselves." 4

Little was accomplished in Washington on the project, and would not have if a waitress at the Howard Johnson's in Dover, Delaware had not reminded Africa that the United States was racially segregated by refusing to 
serve Ghanaian Finance Minister K. A. Gbedemah a glass of orange juice.

The well-reported incident sent the White House scurrying to control the damage, and Gbedemah was given the invitation to see the President that he had up to now been denied. Gbedemah was too clever to waste this opportunity to push the Volta project, and for Eisenhower this was apparently the first time he had heard of it. Afterwards, Carl Flescher of the International Cooperation Agency (ICA) was asked to work up a proposal before the mid-summer state visit of Prime Minister Nkrumah. 5

Since the project had been first envisioned in 1900, numerous studies of the project had been made, the latest being the 700 page Jackson report, which estimated the cost at $\$ 900$ million for a hydroelectric dam, a power plant, aluminum smelter, a railroad network, towns and a new port. Initially Alcan of Canada and British Aluminum had been interested but had reconsidered by the time of Ghana's independence. In mid 1957, an American entrepreneur, Fraser Leith, was given a ninety-day option to raise capital to finance the project. While Leith got nowhere, he did interest the Department of State enough for it to consult aluminum-industry executives. One of those consulted was Chad Calhoun, a vice president of Kaiser Industries and Edgar Kaiser's contact man in Washington. Calhoun was more concerned with obtaining a contract for his company's 
construction division, but he hinted that Kaiser Industries might eventually help finance the project, providing they got the construction job. 6

It was to Calhoun that Flescher now turned for advice. As he saw it the United State's role would be to lend the Ghanaians enough capital to build the dam and power station, while private investors would build the aluminum smelter. Flescher's problem was finding a company which was ambitious enough to risk the capital. By spring he concluded that only a consortium could handle the risk. In mid July, he asked Calhoun the cost of an engineering study of the project. Calhoun said that Kaiser could do it for $\$ 120,000$. Flescher told State Department officials to arrange a meeting between Calhoun and Nkrumah during Nkrumah's upcoming visit to the United States. 7

On July 23, Nkrumah arrived in America and was met by Nixon. Later that day he met with Eisenhower to discuss the Volta project, foreign aid, U.S. relations with Africa and the U.S. peacekeeping mission in Lebanon. Seeing an issue with which he could ingratiate himself with Eisenhower, he supported the U.S. position on Lebanon wholeheartedly. ${ }^{8}$ The next day, Nkrumah, finding off questions from the National Press Club, responded to the question of whether there was a "communist element in Ghana" by saying: "We in Ghana.. . do not allow the ideology to have any fruitful set-up in our country." 9 on racial 
discrimination in America, Nkrumah said that this problem has been "exaggerated deliberately by those who hoped to bring the country into disrepute."10 Later that day, Nkrumah addressed the Senate, calling for more American investment and aid for Africa.

The next day Nkrumah made a major speech before the Council on Foreign Relations, where he explained Ghana's non-alignment, which he said "could only be understood in the context of the cold war." He compared it to nineteenth century American policy of non-entanglement, and denied that it implied "indifference to the great issues of the day." He said that on the great issue of war and peace Ghana "puts all its weight behind the peaceful settlement of disputes" through the United Nations and that Ghana accepted "every provision of the UN Charter."11

Nkrumah then appealed for foreign assistance for Africa, arguing that aid expanded trade, and that it was "the surest guarantee of permanent friendship between Africa and the West." He discussed what Kennedy associate Harlan Cleveland called the "revolution of rising expectations!" "The hopes and ambitions of the African people have been planted and brought to maturity by the impact of Western civilization," he said, but "it has forced the pattern upon us. - We can not tell our peoples that the material benefits and growth and modern progress are not for them. If we do, they will throw us out." Therefore, Nkrumah 
argued that Africa must modernize, either with western support or with the help from "elsewhere": "This is not a warning or a threat, but a straight statement of political reality."12

On the 27th, as Nkrumah was preparing to leave for New York, the White House released the Eisenhower/Nkrumah joint communique. In it the two governments first affirmed their bonds of friendship, then turned to the matter of the Volta project. The two governments "explored the types and scope of assistance which the United States Government might be able to extend." The United States "expressed appreciation of the contribution" of the project to Ghanaian development and "agreed to continue to explore with private American interests . . how it might assist with loans if the private financing were pressured." However, the United States made no commitments. In other clauses, the governments agreed that U.S. troops should remain in Lebanon until they could be replaced by a UN peacekeeping force, they "exchanged views on the emergence of new African states" and the President "noted with deep interest . . the development of a distinctive African personality, emphasized in this connection the sincere interests of the United States in the orderly political, economic and social advancement" of Africa. 13

The following day Nkrumah appeared on the Meet the Press show on NBC. The first questions asked dealt with 
neutralism and Lebanon, which Nkrumah answered by repeating statements made early in the trip. He was then asked if he thought the United States was imperialist. "That all depends on what you mean by imperialism," Nkrumah said, "but as far as I know, I don't think the United States is imperialist."14 Nkrumah later explained that although he believed in the Marxist "philosophy," he "never found it incompatible with private investment." Asked if he had "obtained any promises of help" relating to the Volta project, he admitted he had not, "but the atmosphere is so congenial, I hope something may come out of it."15

Nkrumah spent the rest of the trip publicizing Africa, Ghana, and the cocoa trade. He made a triumphful return to Lincoln University, rode a motorcade through Harlem crowds, lunched with New York Governor Averell Harriman, visited the New York Cocoa Exchange, the New York Stock Exchange, and various trade agencies. His travels were heavily covered by the mass circulation and black press. 16

On August 1, Nkrumah had an unpublicized meeting with Edgar Kaiser at the Waldorf-Astoria in New York, which perhaps was the most important of the entire tour. Earlier that week Nkrumah had met with Calhoun and agreed to split the cost of a Kaiser Industries engineering survey of the Volta project. The purpose of meeting was to allow Kaiser to make his own assessment of Nkrumah's personal stock. The 
meeting was a success. Kaiser decided that "Nkrumah was a man to be trusted" and Nkrumah sensed that things were finally moving on the project. He invited Kaiser to visit him in Ghana that september and urged him to begin the survey immediately. 17

Nkrumah returned to Ghana on August 8, without any commitments from the United States but optimistic about the future of the Volta River project and U.S. relations in general. The Volta project had been put on the United states foreign policy agenda. It had been discussed in the New York Times and in the Council of Foreign Relations. From this point on few articles on Ghana would omit mention of it. Although the Republican administration had showed little interest, Democrats such as Adlai Stevenson, Senator John F. Kennedy, and New York Governor Averell Harriman became supporters of the project.

In September, Kaiser made his trip to Ghana, and the engineering crews soon followed and began the survey. In February 1959, the report was released, and it envisioned a price of $\$ 300$ million for the dam, power station, smelter, and a 500 mile transmission net, which would enable 60 percent of the projects power to reach buyers. That March, Kaiser returned to Accra to discuss the report. Nkrumah gave Kaiser the contract to draw-up specific plans (his company ultimately won $\$ 25$ million worth of construction contracts on the project) and urged him to invest in the 
smelter. Kaiser declined because Alcan had recently began an attempt to form a consortium and he did not want to muddy the waters. However, by summer Alcan had made little progress. Kaiser "slowly reached the decisions. One was that if a consortium were to be formed, he was going to have to take the lead himself. The other was that, by one means or another, the U.S. Government had to back the Volta project." 18

In August, Kaiser received a call from Nathaniel Davis, Alcan president, who told him that his company was giving up. Kaiser penned a memo to Calhoun "Nat called. We've got the ball." However, the ball did not seem to be moving anywhere. Calhoun found few sympathetic ears in the State Department. Kaiser was able to get representatives of Alcan, Alcoa, Olin Mathieson, and Reynolds to put up $\$ 50,000$ each to form a study group Volta Aluminum Co. (Valco), which later could be turned into a consortium. The formation of Valco convinced the Ghanaians to look for the money for the dam and the power plant. They asked the World Bank to assist them and, in January 1960, the bank sent officials to make a report of the costs. The report released in July 1960 was not good news--it pronounced the $\$ 300$ million cost estimate too low, and was skeptical about the ability of Ghana to sell enough power to make it feasible. At this point Kaiser decided to make a concerted effort to change the World Bank's mind. Discussions were opened and by the 
end of 1960, "the bank was gradually converted to Kaiser's viewpoint." At this point Kaiser had raised interest in the North American aluminum firms and the World Bank. It was now the time for the Department of state to begin talking about financing the project. They did not. It was an election year and Eisenhower was content to serve out his term. Kaiser would have to wait until the next president took office. ${ }^{19}$

On July 3, the Belgium Congo became independent. Within two weeks, its army had mutinied, beginning a crisis which would last four years and irreversibly change the state of African affairs. The Congo Crisis inevitably effected the United States' relations with Ghana. 20 There were two major effects. First, it split Africa into moderate and radical blocs, thereby forcing Ghana to choose sides in the cold war or stand alone. Second, because the major U.S. policy objective in the Congo Crisis was to keep the radical Prime Minister Patrice Lumumba and his associates out of power, and Nkrumah's objective was to keep him in power, there was an irresolvable conflict between the two nations.

The ill will generated by increasingly conflicting views on the Congo came to a head at the $23 \mathrm{rd}$ session of the U.N. General Assembly. Before the Assembly met, Nkrumah conferred with Eisenhower for an hour, then with Premier Nikita S. Khrushchev, "apparently discussing only 
generalities with each." In a joint statement, Nkrumah and Eisenhower affirmed their common loyalty to the United Nations. 21 However, the Eisenhower administration was surprised to hear Nkrumah harshly criticize Western policy on the Congo, call for an all-African command for the UN Congo Force, and urge the admission of the People's Republic of China into the UN.

Nkrumah's remarks diverged sharply from current American foreign policy; none of them attacked, however, the United States or supported specifically Soviet policies. Secretary of State Christian Herter reacted angrily at a meeting of the Foreign Policy Association later that day. "I think Nkrumah," he said, "marked himself as very definitely leaning toward the soviet Bloc."22 The reaction by Ghana was immediate, but not so harsh as to preclude reconciliation. The remark by Herter was both unfair and undiplomatic. Despite his effort to win favor by moderating his rhetoric, Nkrumah had been labeled communist for a few honest disagreements with U.S. policy. Any disagreements should have been argued in camera rather than in the press. The narrowmindedness of Eisenhower's administration left United States-Ghanaian relations in shambles, despite a strong effort by Nkrumah to cultivate the American leadership. All was not lost, however, Nkrumah's message had been noted in other quarters. 


\section{Endnotes}

${ }^{1}$ New York Times, 4 March 1957, $1: 4$.

${ }^{2}$ National Security Council, "Report to the President on the Vice President's Visit to Africa," April 22, 1957, Tab B.

${ }^{3}$ New York Times, 5 March 1957, 5:1.

${ }^{4}$ National Security Council, 9.

5 Phillip Siekman, "Edgar Kaiser's Gamble in Africa," Fortune 64 (November 1961): 130-33. The ICA was the predecessor to the Agency for International Development.

6 Ibid., 133.

7 Ibid., 199.

8 Nkrumah, I Speak of Freedom (New York: Praeger, 1961), 135-50.

${ }^{9}$ Ibid., 139.

${ }^{10}$ Ibid., 140 .

${ }^{11}$ Ibid., $142-43$.

12 Ibid., 145 .

13 "Eisenhower-Nkrumah Joint Statement," New York Times, 27 July 1958, 4:5.

14 "Ghana's Prime Minister Meets the Press," Africa Weekly 4.4 (30 July 1958): 3 .

${ }^{15}$ Ibid. , 4.

16 Kinsey, 100-104.

${ }^{17}$ Siekman, 199-200. 
18 Ibid., 200 .

${ }^{19}$ Ibid., 204-206.

20 see Chapter III.

${ }^{21}$ Kinsey, 114; Dana Adams Schmidt, "Nkrumah Divides

Diplomatic Visits," New York Times, 23 September 1960, $18: 5-6$.

${ }^{22}$ Kinsey, 114; "Herter and Nkrumah," The New Republic

153 (October 3, 1960): 5. For the Ghanaian reaction, see

"Herter and the African," Daily Graphic (Accra),

26 September 1960 . 


\section{CHAPTER VIII}

KENNEDY, THE VOLTA DAM PROJECT AND THE UNITED STATES POLICY TOWARD NEUTRALISM IN PRACTICE

On the even of John F. Kennedy's inauguration in January 1961, Ghana had some reason to suppose that a change in relations with the United States was forthcoming. During the campaign, Kennedy had criticized the Republicans for slighting Africa and treating its nations as "pawns" in the cold war, and he had urged a "no-strings" aid policy. In September, Kennedy had sent Harriman lone of his top advisors) to Ghana "to find out what the United States can do for Ghana in the field of technical aid," 2 and following the election he sent his brother Edward to join a Senate Foreign Relation Committee study mission which was passing through Ghana. 3 In addition, Kennedy was a friend of twenty years to Nkrumah's confident, Barbara Ward Jackson, who urged Kennedy to meet with Nkrumah, whom she considered an independent nationalist. "It is worth a risk and could possibly be a triumph" was her advice. 4

Kennedy's inaugural address also gave Ghana reason for hope. It was published in full in the Evening News and favorably commented on a two-part editorial entitled "A Test of Sincerity," which praised the President's "cognizance of the cry for freedom in Africa, and the crying need for 
assistance to defeat the incredible poverty and disease in the continent." 5 However, the editors warned that while Kennedy had made a "very good speech" in which his concern for Africa was evident, "it is by this very fact that his sincerity will be put to the severest test." 6 Following Kennedy's inaugural, the United States began to get fairer coverage in the Ghanaian press, which up to then had been harshly critical. 7

During the transition period, Kennedy had asked Assistant Secretary of State for Africa G. Mennen Williams to prepare a report examining the Volta River project from the viewpoint of cold war strategy. The report, released January 30, warned that "a major battle in the cold war is being waged in Africa" and that "Ghana is a decisive battle field where the issue still hangs in the balance." If the West would not finance the Volta River project, there was a "real" risk that Ghana would "turn to the East." 8 The report listed five "compelling" reasons for the United States' support: (1) The Volta plan had been a major objective of the Nkrumah government since 1951 and thus was well planned and sound. (2) If the Western aid was not forthcoming, Ghana would turn east. (3) Ghana was the leading African nation--if she was rebuffed, it would damage U.S. relations with all of Africa. (4) Ghana's positive neutralism was no different than India's, with whom America had major aid programs. (5) If the United States refused to 
assist the Volta project, it would have the same effect as Eisenhower's withdrawal from the Aswan Dam project--it would polarize Africa, and increase Soviet influence in the region. 9

One of the report's recommendations was to increase government guarantees to Valco investors: "it is most important that U.S. Government make its policy decisions as to broaden quarantees or direct loans or a combination of both."10 It was decided that the standard ICA guarantee would not suffice. However, Valco negotiators discovered that an obscure clause in the Development Loan Fund Act allowed the Government to make effective guarantees. In February, the state Department put together a preliminary funding program. For the dam and power plant Ghana would provide $\$ 98$ million, the UK $\$ 14$ million, the World Bank $\$ 47$ million with the United states lending $\$ 37$ million through the DLF and Export/Import Bank. For the Valco Smelter, the DLF would guarantee 908 of the $\$ 54$ million provided by Kaiser and Reynolds (the two remaining members of Valco after the withdrawal of Alcan, Alcoa, and Olin Mathieson) and would lend Valco $\$ 96$ million through the Ex-Im-Bank. 11 In March, Nkrumah was scheduled to be in New York for a meeting of the the UN General Assembly. Kennedy took the occasion to invite him to the White House for talks and met him warmly at the airport, an extraordinary gesture considering that it was not a state visit. This was 
followed by a ninety-minute meeting in which Kennedy told Nkrumah of his commitment to the elimination of Portuguese colonialism and that he would soon approve the Volta funding. At a press conference of greetings following the talk, Kennedy emphasized America's revolutionary past and his commitment to end colonialism.

Nkrumah strongly rejected a remark by a reporter which implied he was a communist. He said that the reporter confused anti-colonialism with communism and borrowed from Kennedy's rhetoric by saying that "anti-colonialism was invented by the United States."12 The next day Secretary of State Dean Rusk distanced himself form the Eisenhower policy towards Ghana in response to a question referring to Christian A. Herter's remark about Ghana being in the Soviet camp. "We start from where we are," he replied, and characterized the Nkrumah talks with such adjectives as "fruitful," "profitable," "helpful," and "productive."13 If it was "profitable for Rusk, it was doubly so for Nkrumah. On June 29, Kennedy wrote Nkrumah stating that "all major issues involved in negotiations" for United States financing were resolved, and that his representatives were now working to draft a final document of approval. 14 While the letter did not give final approval, it implied that it was forthcoming. Confident, Nkrumah accepted a $\$ 45$ million bid for the construction of the dam from Impresit, the construction division of Fiat, and began preparations 
for a long planned visit to the Eastern bloc scheduled for mid-July and August. 15

The Kennedy administration was watching the incoming visit with apprehension, and before Kennedy sent his letter of June 29, he asked the state Department to examine the implications of the trip. The resulting report dated June 26 predicted that the visit "will probably usher in a period of even closer relations between Ghana and the soviet Bloc" and that it "may lead to an increased Bloc presence in Ghana." However, the report also emphasized that Nkrumah had resisted Soviet overtures to train Ghanaian army units and that the "army is free of Soviet influence." It cautioned against reading too much into similarities in Ghanaian and Soviet pronouncements since their foreign policies "tend to coincide" on many issues. "Nevertheless, Nkrumah acts independently with respect to specific policy objectives." The report points out areas where Ghana's policy diverges. Nkrumah's support of the UN and his support for "African solutions to African problems" all have the potential for conflict with soviet policy. The conclusion of the report is that Nkrumah "will tolerate Soviet assistance and support only so long as it is not prejudicial to the interests of Ghana and Africa."16

Although the Kennedy administration expected some sympathy between Ghana and Soviet rhetoric, they were surprised by its intensity. The "Iron Curtain tour resulted 
in so apparently fervent an embrace of the communists as to raise new questions about the Volta Dam at just the moment when Abram Chayes [the State Department Legal Counsel] brought the agreement to the point of signature,"17 Arthur M. Schlesinger, Jr. writes. The trip immediately brought about a sentiment both inside and outside of the administration to back out of the plan. Public opinion and Congress were hostile, 18 and after an attack on the United States by Nkrumah at the Belgrade conference of non-aligned nations, Robert F. Kennedy (who had just returned from a visit to Africa) wrote his brother: "We are limited to the amount of money we are going to spend in Africa and it would be better perhaps to spend it on our friends rather than those who have come out against us."19 Only Chayes, Undersecretary Bowles and Williams supported the project within state. On September 18, Kennedy held up approval and began to reassess the decision. 20

Kennedy was apparently still convinced of the project's merit but wanted more time to decide. In early October, Kaiser and Calhoun returned from Ghana with renewed assurances from Nkrumah that there was no change in basic Ghanaian policy. 21 On October 20, Kennedy announced he was sending Clarence Randall and Chayes to review the project. Randall, Eisenhower's former chief foreign economic advisor, and a businessman of unquestionably conservative credentials, pronounced the plan feasible and that Nkrumah 
was not a communist. A clrcular inquiry to African allies registered approval of the plan. 22

That November, British Prime Minister Harold Macmillan wrote Kennedy urging him to go ahead with the project. He did not believe Nkrumah was communist and felt that if Kennedy rejected the plan, it would show Africans that they could not have freedom to criticize the West if they wanted Western assistance, which was not the message he believed Kennedy wanted to send. 23

Meanwhile, the CIA was engaged in its own study of Ghana, which was finished on November 16. The CIA concluded that "we do not believe that President Nkrumah has decided to align himself completely with the Bloc." The report noted that while he believed "he can use the Bloc to further his objectives" he will "maintain a Western presence in Ghana to offset the Bloc and improve his prospects for aid."24 In regard to the Volta project the CIA reported that Nkrumah was beginning to have difficulties obtaining Western aid. "If this trend is aggravated by the West's refusal to honor what is in his view a commitment to finance the Volta River project," the report warned, "Nkrumah will almost certainly react violently and turn even more to the Bloc. " 25

While the administration was carrying on its reassessment, it could not be oblivious to the debate outside it, in the Congress and press. In Congress the plan 
had few supporters, with the liberals opposing it on human rights' grounds, and the conservatives because they felt Ghana was a "new Cuba."26 Within the press, Time magazine and U.S. News and World Report led those opposed, while the New York Times and the New Republic supported the project. 27 Time magazine had been carrying an offensive against Ghana for years, the Volta project being merely the most recent target. The New Republic supported the project, but urged a more realistic assessment of what foreign aid can and can not do.

Its purpose can be nothing more nor less than to forestall, over the long term, the establishment and consolidation of a monolithic Communist world. . . . It cannot be counted on to prevent the countries whose independence we help underwrite from deciding at any particular moment that it is in their national interest to side with the Communists on some international issue. view." 28 will not recruit camp-followers for "our

At the December 5 meeting of the National Security Council the decision to sign the Volta agreement was made. 29 Despite the vigorous opposition of his brother, the support of the plan by Macmillan, Kaiser, Randall, Lady Jackson and the CIA, was too great to derail the project. According to Schlesinger, Kennedy's decision was based on the long-term effect on United States-Ghanaian relations. Until the Volta River project's conclusion in the midseventies, it was assumed that it would be a continuing restraint on Ghana's radicalism. Finally, "his view was 
that the final beneficiaries of the Volta Dam would not be the government of Kwame Nkrumah, but the people of Ghana." 30 . 
Endnotes

${ }^{1}$ See Chapter $\mathrm{V}$.

2 "We Want to Help You--Harriman," Daily Graphic,

2 September $1960,1: 4-5$.

3 "Kennedy's Brother for Ghana," Daily Graphic,

5 December $1960,4: 5-6$.

4 Arthur M. Schlesinger, A Thousand Days: John F.

Kennedy in the White House (New York: Harper and Row, 1965), 498 .

${ }^{5}$ Evening News (Accra), 23 January 1961, 2:3-6.

${ }^{6}$ Ibid., 24 January 1961, 2:1-2.

${ }^{7}$ On the day of Kennedy's inauguration, the headline of the Evening News was "Communist Party Now To Strive for World Peace."

${ }^{8}$ U.S., Department of State, "The Volta River Project and the Valco Aluminum Smelter Project in Ghana," January 30, 1961, 1, 11; quoted in Kinsey, 299.

9"Volta," 12-13; Kinsey, 299.

10 "Volta," 13; Kinsey, 299.

${ }^{11}$ siekman, 206.

12 Rinsey, 152-54; Thompson, 170-71; "President Holds

Talk With the President of Ghana," Department of State Bulletin, 27 March 1961, 445-46; Dana Adams Schmidt, "Nkrumah Confers at White House," New York Times, 9 March $1961,1: 4$. 
Endnotes

${ }^{1}$ See Chapter $\mathrm{v}$.

2 "We Want to Help You--Harriman," Daily Graphic,

2 September 1960, 1:4-5.

3 "Kennedy's Brother for Ghana," Daily Graphic,

5 December 1960, 4:5-6.

${ }^{4}$ Arthur M. Schlesinger, A Thousand Days: John F.

Kennedy in the White House (New York: Harper and Row, 1965), 498 .

${ }^{5}$ Evening News (Accra), 23 January 1961, 2:3-6.

6 Ibid., 24 January 1961, 2:1-2.

${ }^{7}$ On the day of Kennedy's inauguration, the headline of the Evening News was "Communist Party Now To Strive for World Peace."

${ }^{8}$ U.S., Department of State, "The Volta River Project and the Valco Aluminum Smelter Project in Ghana," January 30,1961, 1, 11; quoted in Kinsey, 299.

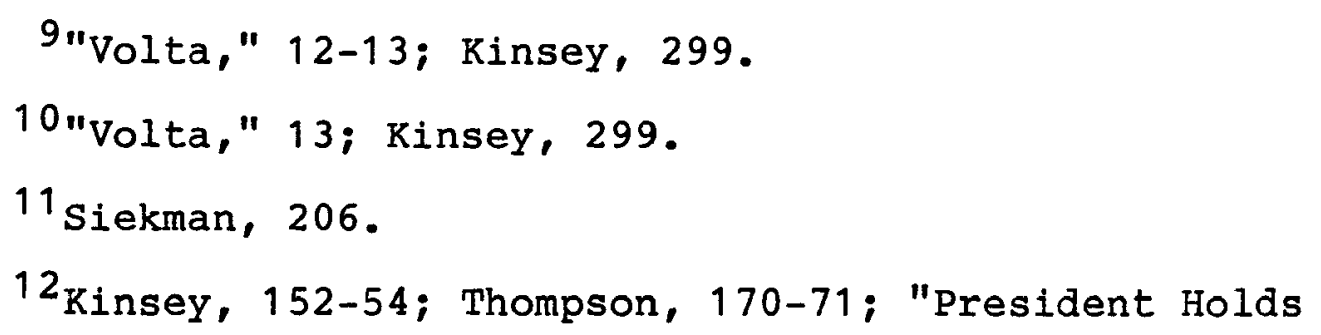

Talk With the President of Ghana," Department of State Bulletin, 27 March 1961, 445-46; Dana Adams Schmidt, "Nkrumah Confers at White House," New York Times, 9 March $1961,1: 4$. 
13 "The Secretary of State's Press Conference," Department of State Bulletin, 27 March 1961.

14 "U.S. Ready To Join With Ghana in Volta River Project," Department of State bulletin, 24 July 1961, 15354 .

${ }^{15}$ Siekman, 206.

${ }^{16}$ U.S., Department of State, "President Nkrumah's Perspective Visit to the U.S.S.R.," Intelligence Report No. 8487,26 June 1961.

${ }^{17}$ Schlesinger, A Thousand Days, 572.

18 Ibid., 572 .

19 Memo, RFK to JFK, 5 September 1961, quoted in Schlesinger, Robert Kennedy and His Times (New York: Bantam, $1979), 604$.

${ }^{20}$ National Security Council, Action Memo No. 96, 18 September 1961 .

${ }^{21}$ Schlesinger, A Thousand Days, 573.

22 Thompson, 191-95.

${ }^{23}$ Schlesinger, A Thousand Days, 572-73.

${ }^{24}$ Central Intelligence Agency, "Prospects for Ghana," SNIE $64.1-61,16$ November 1961,3 .

25 Ibid. , 4 .

26 Schlesinger, A Thousand Days, 572 .

${ }^{27}$ See especially "Nkrumah Leans East," Time,

20 October 1961; "Taking U.S. Aid and Red Ideas," U.S. News 
and World Report, 6 November 1961; and "'Our View' and Their View," The New Republic, 16 October 1961.

28 "Our View," 4.

${ }^{29}$ Schlesinger, A Thousand Days, 573-75; Robert Kennedy and His Times, 604-5.

${ }^{30}$ Schlesinger, A Thousand Days, 573-74. 


\section{CONCLUSION}

The emergence of an independent neutralist Africa changed the dynamics of the cold war. The Eurocentric military-strategic orientation of both the United States and the Soviet Union's foreign policy had little relevance to the underdeveloped nations of Africa. African neutralists wanted the capital and technology to transform their nascent economies, not arms and military treaties. A more political-economic approach was called for.

However both the U.S. and the USSR had serious ideological impediments to such a policy. The Soviet Union believed that the new African nations were tainted with bourgeois nationalism, while the United states, under the leadership of Dwight D. Eisenhower, considered neutralism to be tantamount to active support for their enemies.

After the ascension to power of Khruschev, the Soviets began to reassess their policies and became the first superpower to discard an outdated doctrine that prevented a serious dialogue with neutralist Africa. With an approach that combined economic assistance with active support for African positions in the UN, the USSR constructed a policy that appealed to the economic and political needs of neutralist Africa.

John F. Kennedy saw the policies of the Eisenhower administration as damaging to the U.S.'s stature in Africa 
and determined that the only way to compete with the soviet Union in Africa was to accept neutralism as a reality and to match the Soviets blow for blow in the areas of economic assistance and support for African independence. This was not a matter of liberalism or altruism, rather it was a cold, hard assessment of the political realities of world politics in the second half of the 20 th century.

Ghana was the preeminent neutralist African state. This status was derived partially from its role as the first African nation to attain independence after the war, but was also due to the reputation of its charismatic leader Kwame Nkrumah. Nkrumah was respected across the continent as a spokesman for African unity and a theorist of African socialism, but he was also a pragmatist and sought economic assistance from both superpowers. Despite the cool relationship between Ghana and the United States that had developed during the Eisenhower years, Nkrumah genuinely desired good relations with America.

Ghana became the test case for the Kennedy administration's new policy toward the neutralist states of Africa. In good part this was due to the symbolic importance of Ghana, but a number of other factors were also at play. Ghana was an English-speaking nation. Its history was well known to Kennedy's academic advisors, many of whom had personal ties to its leaders. Finally, Kennedy inherited an opportunity in the Volta River Dam project to 
forge an important tie between neutralist Africa and American industry.

His decision to support the project was a concrete manifestation of his administration's respect for neutralist Africa. For Kennedy's purposes, it mattered little whether the project failed or succeeded in its goals. The important thing was that America was now competing with the Soviet Union in the new playing field of third world opinion. The Volta Dam decision is more than 25 years past, and reflecting back, its legacy is a mixed one. In the last two and a half decades, the United states and the international lending community have supported similar prestige public works projects in developing nations. These projects have contributed little to economic development and greatly to the third world's debt. The Volta Dam itself has never achieved all of its projected technical goals, much less its more ambitious goal of serving as the springboard toward the industrialization of Ghana and then all of Africa. The only clear winners were Philip Kaiser and the companies involved in the construction of the dam and smelter, who could not lose on a project backed by both the U.S. and the World Bank.

However, it could be argued that the Kennedy decision did have its positive effects on the course of African history. Africa is still considered in cold war terms, but the official tolerance of non-alignment is no 
longer a serious issue. Occasionally some ultraconservative group or congressman will attack African nations for their UN voting record, but even the most conservative administration finds the utility of ignoring a nation's foreign policy pronouncements, particularly when, as usually is the case, the country is indebted to U.S. banks and dependent on American goodwill for World Bank development funds.

With some exceptions in southern Africa and the Horn, Africa has for the most part escaped becoming the focus of major cold war conflicts and the full scale interventions of the kind that have plagued Latin America and Asia. This is in good part because Khruschev and Kennedy confined the bulk of their competition to the economic field and their successors have not been inclined to break the precedent.

Also, the acceptance by the United States of independent foreign policies by states receiving assistance has allowed Africans to play a significant role in both African and global relations. African nations like Nigeria and Kenya, which have significant economic and cultural ties to the United States, have nevertheless played important roles in the isolation of South Africa, the promotion of arms control and the formulation of a new international economic order, despite American opposition to these policies. 
Despite the elapse of twenty-five years, many of the issues discussed in this thesis are still relevant. The question of whether the United States should tolerate the independence of nations to whom it provides foreign assistance is as current as the 1980 decision to cut off aid to the socialist Sandinista government in Nicaragua. After eight years of embargo and covert war has resulted in a stalemate, it bears wondering whether a policy resembling Kennedy's Ghana policy may have succeeded where Ronald Reagan and Oliver North's failed. 


\section{BIBLIOGRAPHY}

The Africa League. A New American Policy Toward Africa.

New York, 1960 .

Aluko, Olajide. Foreign Policies of African States. London: Hodder \& stoughton, 1977.

- Ghana and Nigeria, 1957-70: A Study in InterAfrican Discord. London: Rex Collings, 1976 .

Attwood, William. The Reds and the Blacks: A Personal Adventure. New York: Harper and Row, 1967.

Austin, Dennis. Politics in Ghana, 1946-1960. London: Oxford University Press, 1964.

Babaa, Khalid I. and Crabb, Cecil V. "Nonalignment as a Diplomatic and Ideological Credo." Annals of the American Academy 362 (November 1965):6-17.

- "The 'Third Force' and the United Nations."

Annals of the American Academy 362 (November 1965):81-9.

Balewa, Sir Abubaker Tafawa. "Nigeria Looks Ahead." Foreign Affairs 41 (October 1962):131-40.

Ball, George W. The Past Has Another Pattern: Memoirs. New York: W. W. Norton, 1982 .

Barnet, Richard. Intervention and Revolution. New York: Meridian, $1 \overline{968 .}$

Berman, Edward H. The Influence of the Carnegie, Ford, and Rockefeller Foundations on American Foreign Policy: The Ideology of Philanthropy. Albany: State University of New York Press, 1983.

Bing, Geoffrey. Reap the Whirlwind: An Account of Kwame Nkrumah's Ghana from 1950 to 1966. London: Macgibbon $\&$ Kee, 1968.

Bowles, Chester. Africa's Challenge to America. Berkeley: University of California Press, 1956.

- "A Close Look at Africa." Department of State Bulletin 47 (December 31, 1962):1002-7.

- "Foreign Aid: The Great Decision of the Sixties." Department of State Bulletin 44 (May 15, 1961):703-9. 
- Promises to Keep: My Years in Public Life, 1941-

1969. New York: Harper and Row, 1971.

Bretton, Henry L. The Rise and Fall of Kwame Nkrumah: A Study of Personal Rule in Africa. New York: Praeger, 1966 .

Brown, Irene. "Studies on Nonalignment." Journal of Modern African Studies 4 (December 1966):517-27.

Brzezinski, zbigniew. Africa and the Communist World.

Stanford: Stanford University Press, 1963.

Chester, Edward w. Clash of Titans: Africa and United States Foreign Policy. New York: Orbis, 1974 .

Chukwumerije, Ibezim. "The New Frontier and Africa,19611963." Ph.D. dissertation, State University of New York at Stonybrook, 1976.

Crabb, Cecil V. The Elephants and the Grass: A Study of Nonalignment. New York: Praeger, 1965.

- "The United States and the Neutralists: A Decade in Perspective." Annals of the American Academy 362 (November 1965): $92-101$.

Daily Graphic (Accra, Ghana). 1961-1962.

Decraene, Phillippe. "Sekou Toure Turns His Back on the World." Reporter 26 (February 1, 1962): 24-6.

Dei-Anang, Micheal. The Administration of Ghana's Foreign Relations, 1957-1965: A Personal Memoir. London: Athlone, 1975 .

Dulles, John Foster."The Cost of Peace." Department of State Bulletin 29 (June 18, 1956):999-1000.

- "Dynamic Peace."Department of State Bulletin 41 (May 6, 1957): 714-6.

- "Peace Without Fear." Department of State Bulletin $24(1951): 725-8$.

Duignan, Peter and Gann, L. "A Different View of United States Policy in Africa." Western Political Ouarterly 13 (December 1960): 918-23.

Eisenhower, Dwight D. The White House Years. 2 vols. New York: Doubleday, 1963-5. 
Emerson, Rupert. "American Policy in Africa." Foreign Affairs 40 (January 1960): 303-15.

Evening News (Accra, Ghana). 1959-1963.

Fedorenko, Nikolai. "The Soviet Union and African Countries." Annals of the American Academy 354 (July 1964): 1-8.

Fleming, D. F. "Is Containment Moral?" Annals of American Academy 362 (November 1965): 18-27.

Gareau, Frederick H. "The Impact of the United Nations Upon Africa." Journal of African Studies 16 (December 1978): $565-78$.

Ghana. The Volta River Project: Statement by the Government of Ghana, 20 February 1961. Accra, Ghana: Government Printer, 1961.

Ghana. The Volta River Project: Statement by the Government of Ghana, January 1962. Accra, Ghana: Government Printing Department, 1962 .

Good, Robert C. "Four African Views of the Congo Crisis." Africa Report 6 (June 1961): 3-15.

"Why Guinea Looks East." New Republic 142 (June $13,1960): 10-12$.

Gurtov, Melvin. The United States Against the World. New York: Praeger, 1974 .

Halberstam, David. The Best and Brightest. New York: Random House, 1969 .

Hilsman, Roger. To Move a Nation: The Politics of Foreign Policy in the Administration of John F. Kennedy. Garden City NY: Doubleday and Company, 1967.

Hoopes, Townsend. The Devil and John Foster Dulles. Boston: Little, Brown, 1973 .

Horne, Alistair. A Savage War of Peace: Algeria, 1954-1962. New York: Penguin, 1977 .

Houphouet-Boigny, Felix. "Black Africa and the French Union." Foreign Affairs 35 (July 1957):89-98.

Howe, R. W. Along the Afric Shore: A Historic Review of Two Centuries of U.S.-African Relations. Westport: Greenwood, 1975. 
India. Ministry of External Affairs. "Asian African Conference: Final Communique." Foreign Affairs Record 1 (April 1955): 67-79.

Jansen, G. H. Afro-Asia and Nonalignment. London: Faber and Faber, 1966 .

Johnson, J. C. de Graft. Background to the Volta River Project. Kumasi, Gold Coast: Abura Printing Works Ltd., 1955.

Kalb, Madeleine. Congo Cables. New York: Macmillan, 1982.

Kennan, George F. "The Sources of Soviet Conduct." Foreign Affairs 25 (July 1947):566-82.

Kennedy, Senator John F. The Strategy of Peace. New York: Harper and Row, 1960 .

Kesaris, Paul, ed. CIA Research Reports: Africa, 1946-1976. Frederick MD: A Microfilm Project of University Publications of America, Inc., 1983.

- Documents of the National Security Council, 19471977 . Washington DC: A Microfilm Project of Univer$\overrightarrow{\text { sity }}$ Publications of America, Inc., 1980.

- O.S.S./State Department Intelligence and Research Reports. Volume XIII: Africa, 1941-1961. Washington DC: A Microfilm Project of University Publications of America, Inc., 1980.

Khrushchev, Nikita S. Khrushchev Remembers. New York: Bantam, 1971 .

- "On Peaceful Coexistence." Foreign Affairs 38 (October 1959): 1-18.

Kinsey, Winston Lee. "The United States and Ghana, 1951-1966." Ph.D. dissertation, Texas Technological University, 1969 .

Kolarz, Walter. "The Impact of Communism on West Africa." International Affairs 38 (April 1962): 152-69.

- "West African Scene." Problems of Communism 10 (November-December 1961):15-24.

Laquer, Walter 2 . "Communism and Nationalism in Tropical Africa." Foreign Affairs 39 (July 1961): 610-22. 
Legvold, Robert. Soviet Policy in West Africa. Cambridge: Harvard University Press, 1970.

Lewis, W. A. "Neutralism in Africa." Reporter 29 (November $10,1965): 31-33$.

Logan, Rayford W. "Is There an Afro-Asian Bloc?" Current History 40 (February 1961): 65 .

Mahoney, Richard D. JFK: Ordeal in Africa. New York: Oxford University Press, 1983 .

Mckay, Vernon. Africa in World Politics. New York: Praeger, 1963.

- The United States and Africa. New York: Columbia University Press, 1958 .

- "A United States Policy for the New Africa."

Current History 37 (July 1959):1-6.

Marin, Y. "Soviet Policy in Africa." Bulletin of the

Institute for the Study of the U.S.S.R. 11 (June 1964): 17-21.

Martin, Lawrence $w$. ed. Neutralism and Nonalignment: The New States in World Affairs. New York: Praeger, 1962 .

Mazrui, Ali A. Africa's International Relations: The Diplomacy of Dependency. London: Heinemann, 1977.

Melady, Thomas P. "Nonalignment in Africa." Annals of the American Academy 362 (November 1965): 52-61.

Mohan, Jitendra. "Ghana Parliament and Foreign Policy, 19571960." The Economic Bulletin of Ghana 10 (1966):29-52.

Morison, David L. "Communism in Africa: Moscow's First Steps." Problems of Communism 10 (November-December 1961): 8-15.

- The U.S.S.R. and Africa. London: Oxford University Press, 1964 .

Morris, Milton D. "The Soviet Africa Institute and the Development of African Studies." Journal of Modern African Studies $11(1971): 247-65$.

Morrow, John H. First Ambassador to Guinea. New Brunswick: Rutgers University Press, 1968 . 
Mosely, Philip E. "Soviet Policy in the Developing Countries." Foreign Affairs 43 (October 1964): 87-98.

Mosley, Leonard. Dulles: A Biography of Eleanor, Allen and John Foster Dulles and Their Family Network. New York: Dial, 1978.

National Security Council. "Report to the President on the vice President's Visit to Africa". 22 April 1957.

New York Times. 1957-1963.

Neilson, Waldemar A. The Great Powers and Africa. New York: Praeger, 1969.

Nkrumah, Kwame. Africa Must Unite. New York: International Publishers, 1963 .

- Challenge of the Congo. New York: International Publishers, 1967.

- Ghana: The Autobiography of Kwame Nkrumah. New

York: International Publishers, 1957.

- I Speak of Freedom: A Statement of Africa Ideo-

logy. New York: Praeger, 1961 .

- The Revolutionary Path. New York: International

Publishers, 1973 .

Noer, Thomas J. "The New Frontier and African Neutralism: Kennedy, Nkrumah and the Volta River Project." Diplomatic History 8 (1984): 61-79.

- "'Non-Benign Neglect': The United States and Black Africa in the Twentieth Century" in American Foreign Relations: A Historiographical Review edited by Gerald K. Haines and J. Samuel Walker, Westport CT: Greenwood, 1981.

Nurse, Ronald J. "Critic of Colonialism: JFK and Algerian Independence." The Historian 39 (February 1977).

Olympio, Sylvanus. "African Problems and the Cold War." Foreign Affairs 40 (October 1961): 50-7.

Parmet, Herbert S. Jack: The Struggles of John F. Kennedy. New York: Dial, 1980 .

Pauker, Guy J. "The Rise and Fall of Afro-Asian Solidarity." Asian Survey 5 (September 1965): 425-32. 
Pistrak, Lazar. "Soviet Views on Africa." Problems of Communism 11 (March-April): 24-31.

Potekhin, Ivan I. "The African Peoples Forge Unity." International Affairs (Moscow) No.6 (1961): 80-84.

- "On African Socialism." International Affairs

(Moscow) No.1 (1963): 71-9.

- "Some Aspects of the National Question in Africa." World Marxist Review 4 (November 1961): 41-6.

- "Stalin's Theory of Colonial Revolution and the National Liberation Movement in Tropical and South Africa." in Thomas Perry Thornton ed., The Third World in Soviet Perspective. Princeton: Princeton University Press, 1964 .

Plyshevsky, I. "Some Problems of the Independence Struggle in Africa." World Marxist Review 4 (July 1961): 32-9.

Quaison-Sackey, Alex. Africa Unbound: Reflections of an African Statesman. New York: Praeger, 1963.

Rooney, David. Kwame Nkrumah: The Political Kingdom in the Third World. New York: St. Martin's Press, 1988 .

Reshetar, John S. "The Soviet Union and the Neutralist World." Annals of the American Academy 362 (November $1965): 102-12$.

The Revolutionary Movement in the Colonies: Theses Adopted by the World Congress of the Communist International. New York: Worker's Library Publishers, 1929.

Rivkin, Arnold. Africa and the West: Elements of Free-World Policy. New York: Praeger, 1962 .

- "Principal Elements of United States Policy Towards Underdeveloped Coutries." International Affairs 37 (October 1961): 452-64.

Rudin, H. R. "Guinea Outside the French Community." Current History 37 (July 1959): 13-6.

Schlesinger, Arthur M. The Life and Times of Robert F. Kennedy. New York: Bantam, 1979 .

- A Thousand Days: John F. Kennedy in the White House. New York: Harper and Row, 1965. 
Senghor, Leopold Seder. "West Africa in Evolution." Foreign Affairs 39 (January 1961): 240-46.

Shepherd, George w. "The Conflict of Interest in American Policy on Africa." Western Political Quarterly 12

(December 1959): 996-1004.

- Nonaligned Black Africa. Lexington, Mass.: D. C. Heath, 1970 .

Siekman, Phillip. "Edgar Kaiser's Gamble in Africa." Fortune

64 (November 1961): 130-33.

Sorenson, Theodore. Kennedy. New York, Harper and Row, 1965.

Stevenson, Adlai E. "New Africa: A Guide and a Proposal." Harpers 220 (May 1960): 48-54.

Thompson, Vincent Bakpetu. Africa and Unity: The Evolution of Pan-Africanism. New York: Humanities Press, 1970 .

Thompson, W. Scott. Ghana's Foreign Policy, 1957-1966:

Diplomacy. Ideology and the New State. Princeton:

Princeton University Press, 1969.

Thornton, Thomas Perry. ed. The Third world In Soviet Perspective. Princeton: Princeton University Press, 1964

Toure, Sekou. "Africa's Future and the World." Foreign Affairs 41 (October 1962):141-51.

"U.S. Economic Aid to Africa." Africa Report 9 (December $1964): 8-12$.

U.S. Congress. Senate. Committee on the Judiciary Subcommittee of Internal Security. The Attempted Communist Subversion of Africa Through Nkrumah's Ghana. Committee Print. Washington DC: Government Printing office, 1979.

U.S. Department of State. Department of State Bulletin. 19561963.

U.S. Department of State. "President Nkrumah's Perspective Visit to the U.S.S.R." Intelligence Report No. 8487, 26 June 1961.

U.S. Department of State. "The Volta River Project and the Valco Aluminum Smelter Project in Ghana." 30 January 1961.

U.S. President. Public Papers of the Presidents of the United States. Washington, D.C.: Office of the Federal Regis- 
ter, National Archives and Records Service, 1953Dwight D. Eisenhower, 1956-1960.

U.S. President. Public Papers of the Presidents of the United States. Washington, D.C.: Office of the Federal Register, National Archives and Records Service, 1961John F. Kennedy, 1961-1963.

U.S. Congress. Senate. Committee on Foreign Relations. Subcommittee on Africa. Hearings Before the Committee on Foreign Relations, Part 1. 86 th Cong., 2n. sess., 1960 .

U.S. Congress. Senate. Committee on Foreign Relations. Subcommittee on Africa. Study Mission to Africa. September-October, 1961: Report of Senators Albert Gore, Philip A. Hart, and Maurine B. Neuberger. 87 th Cong., lst sess., 1962 .

U.S. Congress. Senate. Judiciary Committee. Subcommittee on Internal Security. Is U.S. Money Aiding Another Communist State? 87 th Cong., 2n. sess., 1963.

U.S. Department of State. The Sino-Soviet Economic offensive in the Less Developed Countries. European and British Commonwealth Series Publ. No.51 (1958).

U.S. Department of State. "Statement by Walter M. Kotschnig, Director of the Office of International Economic and Social Affairs, before the Third Session of the U.N. Economic Commission for Africa in Addis Ababa, Ethiopia, February 6-17." Department of State Bulletin 44 (March 13, 1961):376-81.

U.S. Department of State. The Threat of Soviet Economic Policy. European and British Commonwealth Series No.62 (1961).

U.S. Department of State. Bureau of Intelligence and Research. World Strength of the Communist Party Organizations. Intelligence Report No. $4489 \mathrm{R}-13$ (1961); R-14 (1962); R-15 (1963).

United Nations. General Assembly. Fourteenth Session. "Address by H.E. Mr. Sekou Toure, President of the Republic of Guinea." Official Records (November 5 1959): 551-51.

United Nations. General Assembly. Fifteenth Session. "Speech by Mr. Sekou Toure, President of the Republic of Guinea." Official Records (October 10 $1960)$ : 563-75. 
Walters, Ronald W. "Formulation of United States Foreign Policy Toward Africa, 1958-1963." Ph.D. dissertation, The American University, 1971.

Walton, Richard J. Cold War and Counterrevolution: The Foreign Policy of John F. Kennedy. New York: Viking, 1972.

Weissman, Stephen. American Foreign Policy in the Congo, 1960-1964. Ithaca: Cornell University Press, 1974 .

Williams, G. Mennen. "Africa's Challenge to America's Position of Free World Leadership." Department of State Bulletin 44 (June 12, 1961): 911-14.

- "Africa: Challenge to American Trade Unions." Department of State Bulletin 45 (July 3, 1961): 25-8.

- Africa for the Africans. Grand Rapids, Mich.: William B. Eerdmans, 1969.

- Basic United States Policy in Africa." Department of State Bulletin 45 (October 9, 1961) $\overline{: 600-603}$.

- "The Challenge of Africa to the American Citizen." Department of State Bulletin 44 (February 20, 1961): 259-61.

- "Communism's Impact on African Nationalism." Department of State Bulletin 48 (June 3, 1963).

- "Developing Africa's Human and Material Resources." Department of State Bulletin 48 (February 11, 1963): 208-11.

- "Diplomatic Rapport Between Africa and the United States." Annals of the American Academy 354 (July $1964): 54-64$.

- Mobilizing Economic Resources for Africa." Department of State Bulletin 44 (April 24, 1961): 584-7.

- "Progress and Expectations in Africa." Department of State Bulletin 44 (April 10, 1961): 527-31.

- "Tasks and Opportunities in Africa." Department of State Bulletin 45 (November 20, 1961): $861-65$.

- "The United States and the New Africa." Department of State Bulletin 47 (November 5, 1962): $\overline{690-94}$.

Wolpert, Stanley. A New History of India. New York: Oxford University Press, 1979 . 


\section{VITA}

The author, Kurt Xavier Metzmeier, is the son of Frank Xavier Metzmeier and Barbara Ann Blackburn-Metzmeier. He was born October 13, 1959 in Louisville, Kentucky.

He received the degree of Bachelor of Arts with a major in history from the University of Louisville in May, 1982. From 1982 to 1983 he served as president of the $\mathrm{Nu} \mathrm{Xi}$ Chapter of Phi Alpha Theta.

In September, 1982, he was granted an assistantship in History at the University of Louisville. He received the Pratt Dale Fellowship in History for 1984. In May, 1989, he was awarded the Master of Arts in History. 